107 Royal Netherlands Institute for Sea Research

This is a postprint version of:

de Nooijer, L. J., Spero, H. J., Erez, J., Bijma, J., \& Reichart, G. J. (2014). Biomineralization in perforate foraminifera. Earth-Science Reviews, 135, 48-58.

Published version: http://dx.doi.org/10.1016/i.earscirev.2014.03.013

Link NIOZ Repository: $\underline{w w w . v l i z . b e / n l / i m i s ? m o d u l e=r e f \& r e f i d=240754 ~}$

[Article begins on next page]

The NIOZ Repository gives free access to the digital collection of the work of the Royal Netherlands Institute for Sea Research. This archive is managed according to the principles of the Open Access Movement, and the Open Archive Initiative. Each publication should be cited to its original source - please use the reference as presented.

When using parts of, or whole publications in your own work, permission from the author(s) or copyright holder(s) is always needed. 


\section{Biomineralization in perforate Foraminifera}

2

3 LJ de Nooijer ${ }^{\mathrm{a}, *}$, HJ Spero $^{\mathrm{b}}, \mathrm{J} \mathrm{Erez}^{\mathrm{c}}, \mathrm{J} \mathrm{Bijma}^{\mathrm{d}}$, GJ Reichart $^{\mathrm{a}, \mathrm{e}}$

4

5 a Department of Marine Geology, Royal Netherlands Institute for Sea Research, Landsdiep 4, 6

$7 \quad{ }^{b}$ Department of Earth and Planetary Sciences, University of California Davis, Davis, CA 8

9 ' Institute of Earth Sciences, The Hebrew University of Jerusalem, Jerusalem 91904, Israel. jonathan.erez@mail.huji.ac.il

${ }^{\mathrm{d}}$ Alfred Wegener Institute for Polar and Marine Research, Am Handelshafen 12, Bremerhaven 27570, Germany.jelle.bijma@awi.de

${ }^{\text {e}}$ Department of Geochemistry, Utrecht University, Budapestlaan 4, 3584 CD Utrecht, The Netherlands. gert-jan.reichart@,nioz.nl

*Corresponding author

.

.




\section{Abstract}

In this paper, we review the current understanding of biomineralization in Rotaliid foraminifera. Ideas on the mechanisms responsible for the flux of $\mathrm{Ca}^{2+}$ and inorganic carbon from seawater into the test were originally based on light and electron microscopic observations of calcifying foraminifera. From the 1980's onward, tracer experiments, fluorescent microscopy and high-resolution test geochemical analysis have added to existing calcification models. Despite recent insights, no general consensus on the physiological basis of foraminiferal biomineralization exists. Current models include seawater vacuolization, transmembrane ion transport, involvement of organic matrices and/or $\mathrm{pH}$ regulation, although the magnitude of these controls remain to be quantified. Disagreement between currently available models may be caused by use of different foraminiferal species as subject for biomineralization experiments and/ or lack of a more systematic approach to study (dis)similarities between taxa. In order to understand foraminiferal controls on element incorporation and isotope fractionation, and thereby improve the value of foraminifera as paleoceanographic proxies, it is necessary to identify key processes in foraminiferal biomineralization and formulate hypotheses regarding the involved physiological pathways to provide directions for future research.

\section{Introduction}

All foraminifera make tests although a number of different materials are used in their construction. The 'naked' foraminifera produce tests from organic matter, agglutinated foraminifera use sediment grains as building blocks and calcifying foraminifera use constituents dissolved in seawater to secrete calcium carbonate. Formation of $\mathrm{CaCO}_{3}$ tests plays a significant role in ocean biogeochemical cycles and, more importantly, the fossil remains of calcifying foraminifera are widely used to reconstruct past ocean chemistry and 
environmental conditions. Elemental and isotopic composition of foraminiferal calcite depends on a variety of environmental parameters such as temperature, salinity, $\mathrm{pH}$ and ion concentration (McCrea et al., 1950; Epstein et al., 1951; Boyle, 1981; Nürnberg et al., 1996). These physical and chemical variations are the foundation for developing geochemical proxies that quantify environmental changes through time (see Wefer et al., 1999; Zeebe et al., 2008; Katz et al., 2010 for reviews). For example, the magnesium concentration in foraminiferal calcite $\left(\mathrm{Mg} / \mathrm{Ca}_{\text {calcite }}\right)$ varies primarily with seawater temperature (Nürnberg et al., 1996; Lea et al., 1999; Hönisch et al., 2013) and can be used to reconstruct past sea surface (Hastings et al., 1998; Lea et al., 2000) and deep-water (Lear et al., 2000) temperatures. Reliable application of these proxies requires calibration over a wide range of environmental conditions as well as a thorough understanding of the physiological parameters influencing test formation.

Studies calibrating foraminiferal test composition based on core-tops and controlled growth experiments show that both the chemical and isotopic compositions of these tests are not in equilibrium as defined by inorganic precipitation experiments (Lowenstam and Weiner, 1989; Dove et al., 2003). Microenvironmental controls related to foraminifera physiology have been implicated to explain disequilibrium fractionation in test chemistry (Figure 1). Most foraminiferal species incorporate $\mathrm{Mg}$ with one to two orders of magnitude lower concentration compared to non-biologically precipitated calcium carbonate (Bentov and Erez, 2006; Katz, 1973; Bender et al., 1975). The concentration of barium, on the other hand, is $\sim 10$ times higher in foraminiferal calcite (Lea and Boyle, 1991; Lea and Spero, 1992) compared to inorganic precipitation results (Pingitore and Eastman, 1984). Additionally, elemental concentrations between foraminiferal species can vary by several orders of magnitude (up to two orders of magnitude for Mg; Bentov and Erez, 2006). The biological controls on element 
incorporation and isotope fractionation that cause these offsets are often summarized as 'the vital effect' (Urey et al., 1951; Weiner and Dove, 2003).

Figure 1: Minor and trace element composition of foraminiferal (left) and inorganically precipitated (right) calcite precipitated from seawater (middle). Concentrations are qualitative as they differ between foraminiferal species and depend on environmental conditions. Precipitation rates, ionic strength of the medium and presence of organic compounds are also known to affect partition coefficients. All values are in parts per million (ppm) and based on data in Kitano et al. (1975), Ishikawa and Ichikuni (1984), Rimstidt et al. (1998), Marriott et al. (2004), Morse et al. (2007), Tang et al. (2012) He et al. (2013) for inorganically precipitated calcium carbonates, and Lea and Boyle (1991), Rickaby and Elderfield (1999), Segev and Erez (2006), Terakado et al. (2010), Allen et al. (2011) for foraminiferal calcite composition.

Vital effects comprise 1) chemical alterations of the foraminifers' microenvironment due to physiological processes, 2) cellular controls on the composition of the fluid from which calcite is precipitated and 3) controls on nucleation and crystal growth (e.g. by presence of organic templates). Foraminiferal respiration and/or photosynthesis by symbiotic algae alter the foraminiferal microenvironment chemistry and thereby the conditions in which foraminiferal tests mineralize. Because habitat depth differences in the water column (planktonic species) or migration in the sediment and attachment to plant leaves (benthic species) also modify the calcification environment, these ecological factors are sometimes regarded as being part of the vital effect as well (e.g. Schmiedl and Mackensen, 2006). Ecology-based variability in element incorporation, however, can be accounted for when habitat preferences of foraminiferal species are known. Hence, the term "vital effects" should 
only be used when discussing foraminiferal cellular processes that alter the chemistry of the microenvironment during test mineralization.

To understand the physiological impact on element incorporation and isotope fractionation, the (intra)cellular mechanisms which foraminifera employ to precipitate test $\mathrm{CaCO}_{3}$ must be identified. Biogeochemical mechanisms are involved in regulating concentrations of ions and/or their activity at the site of calcification. Calcification from seawater can be promoted using different mechanisms. Hence, multiple mechanisms have been proposed to explain test calcification, including endocytosis of seawater, transmembrane ion transporters, ion-specific organic templates, production of a privileged space and mitochondrial activity (Spero, 1988; Erez, 2003; Bentov and Erez, 2006; Bentov et al., 2009).

A process-based framework for both inorganic and organismal control of foraminiferal test formation is crucial for the development, calibration and application of geochemical proxies in the geological record. At the same time, a mechanistic understanding of foraminiferal biomineralization will also permit researchers to better interpret data from the fossil record as well as predicting the response of foraminiferal calcification to future environmental changes such as ongoing ocean acidification. Most of the initial observations of chamber formation and calcification in planktonic foraminifera were published during the early period of planktonic foraminifera culturing (e.g. Bé et al., 1977). Highlights of those observations can be found summarized in the seminal text on "Modern Planktonic Foraminifera" (Hemleben et al., 1989). More recently, studying living specimens under controlled conditions (e.g. Kitazato and Bernard, 2014) has further propelled our understanding of foraminiferal growth,

\section{reproduction and calcification.}

Recent hypotheses on foraminiferal biomineralization are based mainly on experiments with benthic species and although these ideas have to be tested for planktonic species, we will also include the latter group in our discussion. Although a general model for foraminiferal 
biomineralization is still lacking, and it is not yet clear that a single model fits all groups of foraminifera, details on the underlying mechanisms in different species have accumulated and are described here in the context of previously published biomineralization models.

\section{Ions for calcification}

\subsection{Seawater as the direct source for $\mathrm{Ca}^{2+}$ and DIC}

Foraminifera calcify by creating a microenvironment supersaturated with respect to $\mathrm{CaCO}_{3}$, while overcoming inhibition by crystallization inhibitors such as $\mathrm{Mg}^{2+}$. Hence, calcification requires a tight control on the concentration and/or ion activity at the site of calcification, commonly referred to as the "delimited" space (Erez, 2003) or "privileged" space. Elevated $\left[\mathrm{Ca}^{2+}\right],\left[\mathrm{CO}_{3}^{2-}\right]$ and/or their ion activities have to be actively maintained in order for calcification to proceed. Simultaneously, the concentrations of crystal growth inhibitors have to be lowered even further. Although $\mathrm{CO}_{3}{ }^{2-}$ needed for calcification may be partially derived from respired $\mathrm{CO}_{2}$ (Erez, 1978; Grossman, 1987; Ter Kuile and Erez, 1991; Hemleben and Bijma, 1994; Bijma et al., 1999), the majority of the carbon and the $\mathrm{Ca}^{2+}$ needed for test formation must be derived from the seawater environment.

Calcification requires equal amounts of $\mathrm{Ca}^{2+}$ and $\mathrm{CO}_{3}{ }^{2-}$. Because seawater $\mathrm{Ca}^{2+}$ concentrations are approximately 5 times higher than that of DIC and often $>50$ times higher than that of $\mathrm{CO}_{3}{ }^{2}$, foraminifera have to spend more time and/or energy in taking up and concentrating DIC than they have to do for $\mathrm{Ca}^{2+}$. A foraminifer needs to process several times the seawater equivalent of its own cell volume in order to acquire enough $\mathrm{Ca}^{2+}$ and inorganic carbon to calcify a new chamber. Although the exact amount needed depends on shape, size and the thickness of the chamber wall (e.g. Brummer et al., 1987), juveniles of some species need 50100 times their own cell volume to extract the $\mathrm{Ca}^{2+}$ required to produce one new chamber (De 
150 Nooijer et al., 2009b). Because seawater $\left[\mathrm{CO}_{3}{ }^{2-}\right]$ is significantly lower than $\left[\mathrm{Ca}^{2+}\right]$, these 151 individuals need the equivalent of $\sim 3,000$ times their own volume in order to take up the 152 necessary $\left[\mathrm{CO}_{3}{ }^{2-}\right]$ if this anion is used exclusively. However, observations of high $\mathrm{pH}$ at the 153 site of calcification (Erez, 2003; De Nooijer et al., 2009a; Bentov et al., 2009) as well as 154 oxygen isotope data from laboratory experiments (Spero et al., 1997; Zeebe, 1999) suggest 155 that foraminifera can convert $\mathrm{CO}_{2}$ and/or $\mathrm{HCO}_{3}{ }^{-}$into the $\mathrm{CO}_{3}{ }^{2-}$ needed for calcification. 156 Evidence that foraminifera concentrate inorganic carbon is also provided by experiments 157 using ${ }^{14} \mathrm{C}$ tracer incorporation kinetics into the skeleton of perforate species (Ter Kuile and 158 Erez 1987, 1988, Ter Kuile et al 1989b). A carbon concentrating mechanism would reduce the 159 volume of seawater necessary for calcification by $50-90 \%$ (De Nooijer et al., 2009b). To 160 concentrate the ions needed for calcification, foraminifera must either extract $\mathrm{Ca}^{2+}$ and 161 dissolved inorganic carbon $\left(\mathrm{CO}_{2}, \mathrm{HCO}_{3}{ }^{-}\right.$and $\mathrm{CO}_{3}{ }^{2-}$, or $\left.\mathrm{DIC}\right)$ or take up seawater and 162 subsequently reduce the concentrations and/or activities of all other ions relative to $\mathrm{Ca}^{2+}$ and 163 DIC (Figure 2). Removal of protons from (endocytosed) seawater is also a prominent feature 164 in recently developed calcification mechanisms, but will be discussed in a separate section 165 (2.2). In case of the second option, spontaneous nucleation of $\mathrm{CaCO}_{3}$ crystals may be 166 prevented by separation of $\mathrm{Ca}^{2+}$ and DIC into different vacuole groups.

Figure 2: Two different mechanisms to concentrate $\mathrm{Ca}^{2+}$ and DIC from seawater for calcification: a) Calcium- and bicarbonate-ions are specifically taken up from seawater, or b) the other ions are selectively removed, thereby increasing Ca and DIC concentrations.

172 Both processes transport ions either directly to the site of calcification or temporarily store 173 these ions. In the case of uptake into some benthic foraminifers, $\mathrm{Ca}^{2+}$ and/ or DIC are thought 174 to be present in so-called 'intracellular reservoirs' (also known as 'pools'; Ter Kuile and Erez, 
1988; Erez, 2003). These reservoirs may be seen as temporal storage compartments with high concentrations of ions that are either emptied upon calcification or provide a dynamic cycling of $\mathrm{Ca}^{2+}$ and DIC through the cell that is gradually used for calcification. Without an intracellular reservoir, $\mathrm{Ca}^{2+}$ and DIC could also be directly transported to the privileged space during calcification (Erez, 2003; Bentov and Erez, 2006). The relative importance of intracellular reservoirs versus direct transport among benthic and planktonic species remains a subject of debate and active research.

\subsection{Internal reservoirs}

Internal reservoirs may be important for foraminiferal calcification in certain groups. Conceptually speaking, one can envision $\mathrm{Ca}^{2+}$ or DIC being derived from internal reservoirs. With seawater as the basis for calcification, carbon reservoirs will have to be approximately 5 times larger than those for $\mathrm{Ca}^{2+}$ or have a 5 times faster turnover rate. Evidence suggests that different foraminifer groups employ different strategies. For instance, a time-lag has been observed between uptake and incorporation of labelled inorganic carbon in the large benthic foraminifera Amphistegina lobifera suggesting inorganic carbon may be stored in an internal reservoir (Ter Kuile and Erez, 1987; 1988; Ter Kuile and Erez, 1991). In pulse-chase experiments it was observed that ${ }^{14} \mathrm{C}$ was incorporated into the calcite during the chase period in ${ }^{14} \mathrm{C}$ free seawater, implying a large internal reservoir of DIC in the benthic Amphistegina lobifera but not in the milliolid Amphisorus hemprichii (Ter Kuile et al 1989b). Isotope labelling experiments with the planktonic foraminifer $G$. sacculifer and a number of benthic species using both ${ }^{14} \mathrm{C}$ and ${ }^{45} \mathrm{Ca}$ show that proportionally more labelled ${ }^{45} \mathrm{Ca}$ is incorporated into the shell compared to labelled ${ }^{14} \mathrm{C}$ (Erez, 1978; 1983). For the planktonic species Orbulina universa and Globigerina bulloides, on the other hand, Bijma et al. (1999) showed that the contribution from an internal carbon pool is insignificant in these species. 
To determine whether planktonic foraminifera have an internal Ca-reservoir, Anderson and

201 Faber (1984) grew G. sacculifer in artificial seawater spiked with ${ }^{45} \mathrm{Ca}$. They showed that

202 calcite formed during the first 24 hours contains significantly less ${ }^{45} \mathrm{Ca}$ than that produced in

203 the second 24 hours. These data argue for the existence of an unlabeled intracellular Ca-

204 reservoir that was filled prior to the introduction of the isotopic spike. Using pulse-chase

205 experiments with both a 'hot' incubation period (10-15 days) and 'cold' chase period (10-20

206 days), Erez (2003) traced the uptake of ${ }^{45} \mathrm{Ca}$ over time in the benthic species Amphistegina

207 lobifera, showing that as much as $75 \%$ of the $\mathrm{Ca}^{2+}$ used during chamber calcification resided

208 in an intracellular reservoir. ${ }^{48} \mathrm{Ca}$ uptake data from experiments using Orbulina universa,

209 supported the existence of a Ca-reservoir in a planktonic species, but demonstrated that it was

210 completely flushed of labelled $\mathrm{Ca}^{2+}$ within the initial 6 hours of chamber formation and

211 thickening (Lea et al., 1995). These latter observations could indicate that $O$. universa utilizes

212 a small $\mathrm{Ca}^{2+}$ reservoir to assist with the initial chamber formation, but that much of the

213 remaining chamber $\mathrm{Ca}^{2+}$ is derived from seawater without passing through an internal storage

214 reservoir.

215 Toyofuku et al. (2008) reported formation of (incomplete) chambers in the benthic Ammonia

216 beccarii maintained in seawater devoid of $\mathrm{Ca}^{2+}$. These data clearly support the existence of a

$217 \mathrm{Ca}^{2+}$-reservoir of finite volume in benthic species. If $\mathrm{Ca}^{2+}$ and other divalent cations that co-

218 precipitate in the $\mathrm{CaCO}_{3}$ shell are derived from the same internal reservoir, one would expect

219 cation concentrations to reflect Rayleigh fractionation if the reservoir is a closed system. Such

220 a system has been used to partly explain minor and trace element distributions in

221 foraminiferal calcite (Elderfield et al., 1996). However, a model using Rayleigh fractionation

222 relies on a number of assumptions about the internal reservoir regarding its size and initial

223 composition as well as refreshment rate and chamber calcification rate. These unknowns

224 highlight the need to better constrain the size and extent of these reservoirs. 
225 To maintain an intracellular reservoir, a foraminifer needs to sustain a high cation flux rate by

226 continuously vacuolizing, endocytosing and exocytosing large volumes of seawater. Tracing

227 endo- and exocytosis in foraminifera is challenging and has yielded contrasting results. For

228 instance, Bentov et al. (2009) showed that in Amphistegina lobifera, seawater is taken up in

229 vacuoles that are subsequently transported to the site of calcification. This implies that

230 seawater, internally modified or not, is directly involved in calcification. De Nooijer et al.

231 (2009b) on the other hand, showed that endocytosis and subsequent exocytosis of seawater in

232 Ammonia tepida are not directly related to chamber formation.

233

234

235

236

\subsection{Direct uptake of ions}

The ions needed for calcification may be derived from seawater during calcification without storage in an intracellular reservoir (Figure 3). A number of calcification models explicitly or implicitly assume that the ions for calcification are passively transported to the site of calcification through diffusion from the surrounding medium (Wolf-Gladrow et al., 1999; Zeebe et al., 1999). These models are able to explain the impact of photosynthetic symbionts on inorganic carbon chemistry in the vicinity of the foraminifer. Changes in $\mathrm{pH}$ and [DIC] due to photosynthesis affect the isotopic composition of the available carbonate (WolfGladrow et al., 1999). However, diffusion of ions to the site of calcification without at least one additional mitigating mechanism, cannot account for the difference between seawater metal composition and $\mathrm{Me} / \mathrm{Ca}$ ratios in foraminiferal calcite (Figure 1 and references in its caption).

Figure 3: Examples of possible involvement of internal reservoirs versus externally derived ions for calcification. $\mathrm{A}$ : $\mathrm{Ca}^{2+}$ and DIC are derived from internal reservoirs. $\mathrm{B}: \mathrm{Ca}^{2+}$ and DIC are transported to the site of calcification without uptake and storage into reservoirs. C: DIC 
250

251

252

253

254

255

256

257

258

259

260

261

262

263

264

265

266

267

268

269

270

271

272

273

274

is taken up directly and $\mathrm{Ca}^{2+}$ comes from an internal reservoir. $\mathrm{D}: \mathrm{Ca}^{2+}$ is taken up during chamber formation and DIC is derived from an intracellular reservoir.

$\mathrm{Ca}^{2+}$ and DIC may be actively transported (through transmembrane pumps and/ or channels) to the site of calcification. Although such transport mechanisms are not yet identified in planktonic foraminifera, a number of studies support the existence of this mechanism in benthic species. Using radioactive labeling, Angell (1979) showed that the ions for calcification are taken up during chamber formation in the benthic species Rosalina floridana. Although this observation does not prove the absence of an internal reservoir per se, this observation reduces the turnover rate and/or size of such a reservoir considerably. Similarly, Lea et al. (1995) showed that the intracellular Ca-reservoir in the planktonic foraminifer $O$. universa is very small and/or has a fast turnover rate and does not significantly contribute to the total amount of $\mathrm{Ca}^{2+}$ during shell thickening. Results from the benthic Ammonia sp. show that intracellular vesicles containing elevated concentrations of $\mathrm{Ca}^{2+}$ are involved in chamber formation (Toyofuku et al., 2008), but that their amount within the cell is not sufficient for the production of a new chamber (De Nooijer et al., 2009b). Together, these studies suggest that the majority of the $\mathrm{Ca}^{2+}$ utilized for shell calcification is not stored in intracellular reservoirs prior to chamber formation in the species studied. If the internal reservoir refills after chamber formation within a relatively short period of time, it is critical that seawater labeling experiments should start directly after a chamber formation event to avoid underestimation of the true reservoir size. Studies addressing the issue of an intracellular reservoir are summarized in Table 1.

Table 1: Studies discussing internal reservoirs in perforate foraminifera. 


\section{Intracellular transport}

\subsection{Transmembrane ion transport}

Due to the hydrophobic inner layer of cell membranes, molecules cannot freely move into or out of the cell's interior. Although the majority of ions and molecules diffuse across cell membranes, diffusion constants vary greatly. Small, uncharged molecules $\left(\mathrm{CO}_{2}, \mathrm{O}_{2}, \mathrm{NO}\right)$ diffuse easily down a concentration gradient whereas large molecules and ions require specialized transmembrane proteins to facilitate or energize membrane transport (Higgins, 1992). These transporter proteins can be divided into channels, carriers and pumps (Figure 4). Carrier proteins undergo substrate binding and transport. They show typical substrate affinities and follow Michaelis-Menten kinetics. Carrier transport is even effective against concentration gradients if a cosubstrate with a respective concentration gradient or charge is involved (secondary active transport). Pumps directly generate this energy for uphill transport from their ATPase activity. Transmembrane channels simply allow facilitated diffusion along electrochemical gradients by creating a selective pore through the cell membrane. For the uptake of inorganic carbon by foraminifera during calcification, a strong $\mathrm{pH}$ gradient (high inside; De Nooijer et al., 2009a; Bentov et al., 2009; low outside; Glas et al., 2012) may promote the influx of $\mathrm{CO}_{2}$ and thus circumvent the need for specialized transmembrane proteins.

Figure 4: selective ion transporters. Ion pumps (left and middle) undergo structural changes that allow passage of ions from and to the binding sites. The example shown here is a simplified $\mathrm{Na}^{+} / \mathrm{K}^{+}$exchanger that has specifically binds to Na-ions (blue squares) when in the first configurational state (left). After the structural change, affinity of the Na-binding sites decreases so that the Na-ions are released (middle). At the same time, K-ions (yellow circles) 
bind to their binding sites after which the pump returns to state one and releases the $K^{+}$to the cytosol. Ion channels (draw after the KcsA $K^{+}$channel; right) consist usually of a narrow pore allowing certain ions to pass a cell membrane down the electro-chemical gradient. Another feature of some pumps and channels is the relatively large cavity that is created by the transmembrane protein-complex (here present in the cytosol-side of the channel). This can greatly reduce the distance that the ions have to be transported. The type of $\mathrm{Ca}^{2+}$-transporters that are used by foraminifera are unknown, but determining their molecular structure is necessary to 1) know the extent of de-hydration during transport, 2) determine the rate of ion transport and 3) explain the selectivity for $\mathrm{Ca}^{2+} /$ against other ions (e.g. $\mathrm{Mg}^{2+}$ ) and their fractionation (e.g. Gussone et al., 2003).

\section{$3.2 \mathrm{Ca}^{2+}$ transport in foraminifera}

In foraminifera, most attention has been directed at ion transporters that might be responsible for the low $\mathrm{Mg} / \mathrm{Ca}$ at the site of calcification. Logically, this may involve $\mathrm{Mg}^{2+}$-transporters and/ or $\mathrm{Ca}^{2+}$ transporters. Because $\mathrm{Ca}^{2+}$ acts as a secondary messenger in most eukaryotic cells, cytosolic $\mathrm{Ca}^{2+}$ is kept low $(<1 \mu \mathrm{M})$ by active removal out of the cell or into cytosolic compartments (ER, mitochondria). This makes $\mathrm{Ca}^{2+}$-transporters one of the most ubiquitous and well-studied transmembrane ion transporters. From a variety of cell types, $\mathrm{Ca}^{2+}$-ATPases, $\mathrm{Ca}^{2+} / \mathrm{H}^{+}$and $\mathrm{Ca}^{2+} / \mathrm{Na}^{+}$antiporters (e.g. Gonçalves et al. 1998) and $\mathrm{Ca}^{2+} /$ phosphate cotransporters (Ambudkar et al., 1984) have been described. Depending on the transporter's structure, ions may pass the membrane either with or without their hydration sphere (Gouaux and MacKinnon, 2005), although (partial) dehydration increases the selectivity greatly (see also Gussone et al., 2003).

The specificity of the transmembrane Ca-transporters varies greatly. For some $\mathrm{Ca}^{2+} / \mathrm{H}^{+}$antiporters it has been reported that other cations with a small ionic radius (e.g. $\mathrm{Zn}^{2+}$ ) can be 
transported in a similar way as $\mathrm{Ca}^{2+}$ is transported (Gonçalves et al., 1999). For the same antiporter, the larger $\mathrm{Ba}^{2+}$ and $\mathrm{Cs}^{+}$do not substitute for $\mathrm{Ca}^{2+}$. An ion with intermediate size, $\mathrm{Sr}^{2+}\left(1.13 \AA\right.$, compared to $0.99 \AA$ for $\left.\mathrm{Ca}^{2+}\right)$, appears to block the antiport and prevents transport of $\mathrm{Ca}^{2+}$ through the membrane. Studies concerning specificity for $\mathrm{Ca}^{2+}$ over $\mathrm{Mg}^{2+}$ are scarce, but some Ca-ATPases have been reported to have a $10^{3}-10^{5}$ higher affinity for $\mathrm{Ca}^{2+}$ than for $\mathrm{Mg}^{2+}$ (Drake et al., 1996; Xiang et al., 2007).

In corals, calcium uptake is directly related to proton pumping (McConnaughey and Whelan, 1997; Sinclair and Risk, 2006). The efflux of $\mathrm{H}^{+}$during calcification (Glas et al., 2012) may therefore help to constrain estimates of calcium pumping rates during calcification. Carbon dioxide uptake and proton efflux are also directly related in cyanobacteria (Ogawa and Kaplan, 1987). Ter Kuile et al. (1989b) suggested that $\mathrm{Ca}^{2+}$ is taken up by $\mathrm{Ca}^{2+}$-ATPase and this mechanism was subsequently used by Zeebe and Sanyal (2002) and Zeebe et al. (2008) to show that $\mathrm{H}^{+}$removal is far more energy-efficient than $\mathrm{Mg}^{2+}$-removal during calcification. Such a mechanism would be consistent with a coupling of ion transporters (e.g. $\mathrm{Ca}^{2+}$ and $\mathrm{H}^{+}$) during foraminifera calcification.

The amount of $\mathrm{Ca}^{2+}$ transported across a membrane depends on 1) transporter density in the membrane, 2) affinity for $\mathrm{Ca}^{2+}$ of the transporter and 3) the capacity of the transporter. For example, the $\mathrm{Na}^{+} / \mathrm{Ca}^{2+}$ exchanger has a low affinity, but high capacity, resulting in transport of up to 5,000 ions per second (Carafoli et al., 2001). Such a transporter is useful when $\mathrm{Ca}^{2+}$ is present in high concentrations (e.g. as in seawater) and supply or removal rates of $\mathrm{Ca}^{2+}$ have to be high. Cell membrane calcium pumps, on the other hand have a high affinity, but low capacity, making it particularly suitable for transporting $\mathrm{Ca}^{2+}$ out of a medium or compartment with a low $\left[\mathrm{Ca}^{2+}\right]$ (Wang et al., 1992). Finally, transport rates can be affected by the presence of inhibitors, high intracellular $\left[\mathrm{Ca}^{2+}\right]$ (e.g. Pereira et al., 1993) or shortage of ATP (in case of e.g. $\mathrm{Ca}^{2+}$-ATPase). 


\subsection{Inorganic carbon transport in foraminifera}

352 Transport of inorganic carbon may be accomplished by bicarbonate-transporters. If seawater or metabolic $\mathrm{CO}_{2}$ contributes to the inorganic carbon during calcification, diffusion rates across membranes would control the influx of inorganic carbon and thereby influence the rate of calcification. The diffusion rate is determined by the concentration gradient of $\mathrm{CO}_{2}$, the membrane area over which $\mathrm{CO}_{2}$ can diffuse, and the solubility of $\mathrm{CO}_{2}$ in the membrane lipids.

357 The concentration of $\mathrm{CO}_{2}$ at the site of calcification or in internal reservoirs is determined by pH. Since foraminifera can control the $\mathrm{pH}$ in these compartments (Erez, 2003; Bentov et al., 2009; De Nooijer et al., 2009a; Glas et al., 2012), they can produce large $\mathrm{CO}_{2}$ concentration gradients and hence promote the influx of DIC to the sites of calcification. The flux of ions can also be calculated from calcification rates, which is discussed in section 4 .

In case of intracellular storage of ions, calcium and DIC are unlikely to be stored as free ions. Because the cytosol has very low concentrations of free $\mathrm{Ca}^{2+}$ and DIC, the cell volume will control the number of ions available for calcification. For the DIC-reservoir (if present) the additional problem is that $\mathrm{CO}_{2}$ can easily diffuse across cell membranes and subsequent reequilibration would thus result in net leakage of carbon out of the DIC-reservoir. To overcome this problem, DIC must be sequestered by mechanisms such as elevating the $\mathrm{pH}$ in the reservoir. Because there are usually no crystallites visible within the cells of hyaline species, $\mathrm{Ca}$ and DIC are likely sequestered together as non-crystalline $\mathrm{CaCO}_{3}$ (i.e. amorphous calcium carbonate or ACC). Such a possibility may have consequences for the minor and trace element composition of the calcite precipitated, since it is known that formation of high-

$372 \mathrm{Mg}$ calcite is accompanied by the formation of an amorphous precursor phase (Raz et al., 373 2000). 
374 Regardless of the process concentrating $\mathrm{Ca}^{2+}$ and DIC from seawater, each would produce a 375 supersaturated solution at the site of calcification, with reduced levels of crystal inhibitors that 376 occur naturally in seawater (e.g. $\mathrm{Mg}^{2+}$ and $\mathrm{PO}_{4}{ }^{2-}$ ). The $\mathrm{Ca}^{2+}$ and $\mathrm{CO}_{3}{ }^{2-}$ may form spontaneous $377 \mathrm{CaCO}_{3}$ crystals, but the specific morphology of foraminiferal chambers show that nucleation 378 and crystal growth is a tightly controlled process.

379

\section{Nucleation of calcification}

\subsection{Crystal nucleation energy and critical size}

Precipitation of a crystal from a solution occurs when free energy of the precipitate is lower than that of the solution. Nucleation of a crystal requires even more energy since ions at the surface of a crystal add to the free energy of the solid phase. This is caused by the fact that ions at the surface of a crystal are not bound on all sides to other ions. The resulting 'interfacial energy' requires the formation of metastable clusters of a critical size to start crystal growth (Figure 5). The interfacial free energy between the cluster and a solution is usually larger than that between the cluster and a solid substrate, resulting in crystal nucleation at solid surfaces rather than within the solution itself (De Yoreo and Vekilov, 2003). If the atomic structure of a substrate matches a particular plane of the nucleating phase (e.g. calcite or aragonite), the interfacial free energy is reduced and nucleation is promoted (De Yoreo and Vekilov, 2003).

In the case of nucleation of $\mathrm{CaCO}_{3}$, presence of negatively charged groups at regular intervals at the site of calcification may be able to bind $\mathrm{Ca}^{2+}$ and pre-form a part of the $\mathrm{CaCO}_{3}$ lattice.

Figure 5: relation between free energy changes ( $\Delta g)$ as a function of pre-nucleation sphere (r), where $\Delta g_{s}$ is the surface term and $\Delta g_{b}$ the bulk term. The sum of $\Delta g_{s}$ and $\Delta g_{b}$ is the free 
energy barrier that can only be overcome by the formation of a nucleation sphere with a critical size $\left(r_{c}\right)$. Biological control over crystal nucleation is often aimed at lowering of this energy barrier and can be achieved by increasing the concentrations of the solutes or the presence of an organic template.

\subsection{Organic templates and nucleation of $\mathrm{CaCO}_{3}$ in foraminifera}

During biomineralization in foraminifera calcium carbonate nucleates at the site of calcification, likely involving an organic template. In all Rotaliid foraminifera, chamber formation starts with delineation of a finite environment that encompasses an inner chamber volume from the surrounding medium (Angell, 1979; Bé et al., 1979; Hemleben et al., 1986; Spero, 1988; Wetmore, 1999). Cytoplasmic activity by formation of a dense pseudopodial network transports vacuoles, mitochondria and organic particles to a defined zone in which the so-called Organic Primary Envelope, Primary Organic Lining, Anlage or Primary Organic Membrane (POM) is formed (e.g. Banner et al., 1973; Hemleben et al., 1977; Spero, 1988; not to be confused with inner and outer organic linings, nor with the outer protective envelope or cytoplasmic envelope: see section 4). The term POM is often used but may be confusing (Erez, 2003) since these organic templates are not technically membranes. Therefore, we recommend following the suggestion of Erez (2003) to rename the POM as the Primary Organic Sheet (POS). In a number of benthic species, the POS consists of unbranched polysaccharides such as glycosaminoglycans (Hottinger and Dreher, 1974; Langer, 1992). Proteins are also present in the organic lining of foraminifera, sometimes forming different classes based on their amino acid composition (Robbins and Brew, 1990). King and Hare (1972) showed that amino acids make up $0.02-0.04 \%$ of the weight of the calcite and that composition among planktonic species varies greatly. Interestingly, the largest compositional difference coincides with the planktonic foraminifera spinose/ non-spinose divide (King and 
Hare, 1972), but differences in amino acid composition are also manifest at lower taxonomic

425 levels (Robbins and Healy-Williams, 1991).

426 The organic matrix of the benthic Heterostegina depressa is shown to contain an EDTA427 soluble and -insoluble fraction (Weiner and Erez, 1984). The insoluble fraction contains oversulphated glycosaminoglycans and a small portion of non-polar proteins, forming the inner organic lining. The soluble fraction contains a number of proteins containing amino acids with acidic residues. Polar groups in both fractions may be involved in biomineralization since they may bind $\mathrm{Ca}^{2+}$ ions and thereby overcome the free energy barrier (Figure 5). If such groups are regularly spaced, they may help nucleation further by placing the $\mathrm{Ca}^{2+}$ ions in a regular grid with just enough space for the $\mathrm{CO}_{3}{ }^{2-}$ ions to fit in between them. To test this hypothesis, the tertiary structures of the biomolecules (e.g. proteins and saccharides) that are involved in $\mathrm{CaCO}_{3}$ nucleation need to be analyzed.

The presence of polysaccharides and proteins has led to the hypothesis that the POS has two 437 functions in the process of calcification. The carbohydrates may form a structure determining the overall shape of the new chamber. The proteins associated with the polysaccharides, on the other hand, form the 'active' part of the POS by providing charged sites for nucleation of $\mathrm{CaCO}_{3}$ (Towe and Cifelli, 1967). Since the chemical composition of the POS varies between species (Banner et al., 1973), its role in nucleation of calcium carbonate may differ between

442 foraminiferal species (Bé et al., 1979; Hemleben et al., 1986; Spero, 1988; Wetmore, 1999). 443 In some benthic species, the POS coincides with the location of the pores prior to calcification 444 (Wetmore, 1999), suggesting that there are structural differences in the POS within a single chamber that determine where calcite does and does not nucleate. In planktonic species such as Globorotalia truncatulinoides and G. hirsuta, calcification begins in small nucleation zones

447 at finite locations across the POS, where calcite forms centers of crystal growth that interlock 448 to form the initial calcified chamber (Towe and Cifelli, 1967; Angell, 1979; Bé et al., 1979; 
Hemleben et al., 1986). A similar pattern has been observed in Orbulina universa, where

450 small islands of calcite form on the POS, followed by calcite island fusion to produce the 451 spherical chamber (Spero, 1988).

452 Nucleation (and subsequent crystal growth) is also determined by the physico-chemical 453 conditions at the site of calcification. These conditions are only partly known in benthic 454 species (e.g. Erez, 2003; Bentov and Erez, 2005) and have only been modeled in planktonic 455 species (Zeebe et al., 1999; Zeebe and Sanyal, 2002). The volume between the crystal surface 456 and the shielding cytoplasmic envelope or pseudopodial network is extremely small, limiting interpretation from light microscopic observations. However, TEM images of initial calcification in Orbulina universa and other planktonic species suggests the privileged space between rhizopodia and calcifying surfaces may be <10 nm (Bé et al 1979; Spero 1988). Little is known about the chemical composition of the fluid from which $\mathrm{CaCO}_{3}$ nucleates, but high concentrations of $\mathrm{Ca}^{2+}$ and $\mathrm{CO}_{3}{ }^{2-}$ need to be actively maintained, while the $\left[\mathrm{Mg}^{2+}\right]$ needs 462 to be reduced to satisfy observations and ensure calcification (Zeebe and Sanyal, 2002). 463 Elevated $\mathrm{pH}$ at the site of calcification would promote the conversion of $\mathrm{CO}_{2}$ and $\mathrm{HCO}_{3}{ }^{-}$to $464 \mathrm{CO}_{3}{ }^{2-}$, thereby enhancing $\mathrm{CaCO}_{3}$ nucleation and growth. Elevated concentrations of $\mathrm{Mg}^{2+}$ 465 around the POS in Pulleniatina obliquiloculata (Kunioka et al., 2006) may indicate that in this species, the composition of the calcifying fluid is different during the first stage of chamber formation, possibly due to a different rate or efficiency of the process that locally reduces $\left[\mathrm{Mg}^{2+}\right]$ vs $\left[\mathrm{Ca}^{2+}\right]$. The participation of a small volume of seawater at the beginning of 469 chamber formation may explain the elevated $\mathrm{Mg}$ in the first calcite precipitated, although this pattern does not hold for other planktonic species (e.g. such as Orbulina universa; Eggins et al., 2004) where the lowest $\mathrm{Mg} / \mathrm{Ca}$ ratios are associated with the intrashell zone that corresponds to the POS. The above observations of inter species differences in chamber wall 
473 elemental composition underscore the need to unravel the mechanisms controlling test 474 calcification.

475

476

477

478

\section{Chamber growth}

After initial crystal nucleation, calcification proceeds by addition of calcite on both sides of the POS. Additional layers of $\mathrm{CaCO}_{3}$ are added on top of pre-existing chamber calcite during each chamber formation event in perforate foraminifera (Reiss, 1957; 1960; Bé and Hemleben, 1970; Erez, 2003). Together, the primary and secondary layers of calcite are termed 'lamellar' calcite (Erez, 2003). Most observations on calcification are based on the first stage of chamber formation in which a thin-walled chamber is produced within 1-3 hours (Spero, 1988). Subsequent thickening of the chamber wall proceeds during the next 24-48 hours until a new chamber is formed. Thickening of earlier formed chambers occurs by addition of a calcite layer with each new chamber formation event (e.g. Bentov and Erez 2005, Nehrke et al., 2013). Future studies will need to show whether the timing of the start and end of chamber formation and thickening of previously formed chambers are coincidental, or whether thickening is a continuous process.

Future biomineralization research should also take into account the possibility that cellular controls on calcification may vary over time and location across the foraminifera shell. An example of the potential complexity and diversity of calcification within one specimen is provided by Bentov and Erez (2005). Their research demonstrated that the benthic Amphistegina lobifera recovering individuals produce at least three types of calcium carbonate: elongated, intracellular birefringent granules with a high magnesium and phosphorus content, extracellular microspheres with a high $\mathrm{Mg}$ concentration and 
500 During chamber formation, ions could be supplied to the site of calcification (SOC) from internal reservoirs (Figure 3, Table 1) or by transport from the surrounding seawater. The latter can be accomplished by transmembrane ion transporters (section 2), by direct exchange of the calcifying fluid with seawater and/ or by diffusion from ambient seawater. The inner and outer surfaces of newly formed chambers of the benthic Heterostegina depressa are covered by thin layer of cytoplasm (Spindler, 1978), suggesting the SOC may be separated from the surrounding medium. In a number of studies (Angell, 1979; Bé et al., 1979), a fanlike arrangement of the pseudopodial network is observed in a zone outside the site of calcification. Although the relation between this arrangement and calcification remains to be investigated, it is likely to play a role in biomineralization since this dense network is not observed between chamber formation events. Also in the planktonic species G. hirsuta and $G$. truncatulinoides, calcification proceeds adjacent to a cytoplasmatic envelope (or outer

512 protective envelope) that may play a role in maintaining SOC integrity and shape, and 513 promoting initial calcification (Bé et al., 1979). In the benthic Ammonia sp., a pH gradient of

$514>2 \mathrm{pH}$ units is observed across several $\mu \mathrm{m}$ distance and is maintained for hours between the 515 site of calcification (De Nooijer et al., 2009a) and the specimen's microenvironment (Glas et 516 al., 2012). These observations suggest that in Ammonia sp., the SOC is separated from the 517 outside environment. Spero (1988) on the other hand, presented transmission electron 518 micrographs that showed the site of calcification in O. universa is not shielded by a 519 continuous membrane. Nehrke et al. (2013) recently suggested that the site of calcification in 520 Ammonia aomoriensis is largely closed from the surrounding medium, but that a small 521 percentage of the fluid at the SOC is derived from leakage of the cell membranes separating it 522 from the outside medium, explaining observed $\mathrm{Mg} / \mathrm{Ca}$ for the species studied. 
523 The extent to which the site of calcification is open or closed, in combination with the

524 presence or absence of intracellular ion reservoirs, is an important unknown in understanding

525 foraminiferal calcification (Figure 6). For example, a site of calcification that is physically

526 separated from the surrounding seawater, together with the absence of intracellular ion

527 reservoirs, prescribes the need for transmembrane ion transporters (e.g. $\mathrm{Ca}^{2+}$-APTase; section

528 II) that selectively pump ions from seawater to the SOC. A SOC that is open, on the other

529 hand, will experience relatively high concentrations of $\mathrm{Mg}$ and require an active $\mathrm{Mg}^{2+}$ -

530 removal mechanism.

531

532 Figure 6: summary of the most important parts of the calcification mechanism in

533 foraminifera, including Ca-ion transport, active Mg-removal and contribution from internal

534 reservoirs. See text for description of the individual processes.

536 Potential ion transport pathways to the site of calcification can be constrained from

537 calcification rates during chamber formation. It is important to distinguish between the overall

538 growth rate of a foraminifer and calcite precipitation rate during biomineralization. The

539 difference between these processes results from the episodic nature of growth (chamber

540 addition) in foraminifera. Some planktonic species have been reported to increase the weight

541 of their shell by $13-15 \%$ a day (G. sacculifer; Erez, 1983), but this may vary with

542 environmental conditions (Ter Kuile and Erez, 1984 and references therein). Secondly,

543 chamber addition rates vary over a foraminifer's lifetime, decreasing as the individual ages

544 (Ter Kuile and Erez, 1984). Calcite precipitation rates during chamber addition, on the other

545 hand, are much higher and vary between $0.4-0.9 \mu \mathrm{g} / \mathrm{h}$ in the planktonic foraminifer $G$.

546 sacculifer (Anderson and Faber, 1984), 0.06-0.32 $\mu \mathrm{g} / \mathrm{h}$ in O. universa (Lea et al., 1995) and

$547 \sim 10 \mu \mathrm{g} / \mathrm{h}$ in the benthic A. tepida (De Nooijer et al., 2009b). Since such rates are rarely 
quantified, it is difficult to generalize these values to other species or other conditions. Moreover, calcite precipitation rates can be variable between day and night calcification periods (Erez, 1983; Spero, 1988; Lea et al., 1995). Since incorporation of some elements may depend on precipitation rate (e.g. DePaolo, 2011), it is necessary to quantify these rates across a diurnal time frame when chamber formation is occurring in order to assess the kinetics of element incorporation and thereby proxy-relationships.

Mitochondrial activity may play an important role at the site of calcification and thereby affect trace element incorporation. Besides providing energy, mitochondria pump cytosolic $\mathrm{Ca}^{2+}$ and $\mathrm{Mg}^{2+}$, and therefore modulate the cell's $\left[\mathrm{Ca}^{2+}\right]$ and $\left[\mathrm{Mg}^{2+}\right]$ (Carafoli et al., 2001). This may be particularly important during calcification when the concentration of these ions increases locally. Spero (1988) shows that calcification in O. universa around the POS is associated with pseudopodia containing mitochondria, and hence possibly modulate $\left[\mathrm{Mg}^{2+}\right]$ at the SOC. Similar results can be found in Bé et al (1979) for Globorotalia truncatulinoides. Bentov et al (2009) discuss the possible role of mitochondria in producing metabolic $\mathrm{CO}_{2}$ that eventually accumulate in the alkaline vacuoles as DIC.

Photosynthesis by symbionts may also affect calcification rates. The relative concentrations of DIC species are influenced by symbiont photosynthesis and $\mathrm{CO}_{2}$-uptake during the day (or release in the dark) and the resulting diurnal differences in microenvironment $\mathrm{pH}$ (Jørgensen et al., 1985; Rink et al., 1998; Köhler-Rink and Kühl, 2000; 2005), thereby influencing uptake and availability of inorganic carbon species. In some large benthic foraminifera (Wetmore, 1999), the symbionts are positioned near the POS prior to calcification, suggesting that their activity could enhance calcification. Elimination of symbionts in G. sacculifer resulted in reduced chamber formation rates and early gametogenesis or death of the foraminifera (Bé et al., 1982). Reseeding the aposymbiotic foraminifera with symbionts from donor specimens produced individuals that continued to add chambers and mature at a normal rate. These data 
suggest that symbiont photosynthesis is critical to both nutrition and chamber calcification. Elevated light intensity promotes growth in G. sacculifer (Caron et al., 1982) but not in the benthic foraminifera Amphistegina lobifera in which both photosynthesis and calcification are optimal at relatively low light intensities that are found at 20-30 m water depth (Erez 1978, Ter Kuile and Erez, 1984).

Ter Kuile et al. (1989a), on the other hand, suggested that symbionts and foraminifera compete for inorganic carbon. Erez (1983) and Ter Kuile et al. (1989b) showed that inhibition of photosynthesis in both planktonic and benthic species by the photosystem II inhibitor DCMU, does not affect calcification rates and suggested that it is not photosynthesis itself, but rather light which directly promotes calcification. Finally, Ter Kuile et al (1989a) have shown that there is competition for $\mathrm{CO}_{2}$ between the symbionts and their host in the benthic foraminiferan A. lobifera. Clearly, the relationship between symbioses and foraminifera calcification requires additional study.

Pore formation provides important information on foraminiferal biomineralization. In species producing macropores, we observe a pore plate that is continuous with the POS and separates the cytoplasm from the outside medium (Hemleben et al., 1977). In benthic, symbiont-bearing species, symbionts can be found in close proximity to the pores (e.g. Lee and Anderson, 1991) suggesting that respiratory gases such as $\mathrm{CO}_{2}$ and $\mathrm{O}_{2}$ may be able to diffuse through the pore plates. In symbiont-barren species, diffusion of gases between cytoplasm and environment could be enhanced by the permeability of a pore plate. Some have suggested that dissolved organic matter may be taken up through the pores in the benthic Patellina (Berthold, 1976). In G. sacculifer, pseudopodia appear to penetrate through the pore plates (Anderson and Bé, 1976). Pores in the benthic species Patellina corrugata have been reported to exist from the beginning of chamber formation (Berthold, 1976) and pores are observed in the O. universa sphere once initial calcification has locked in the spherical morphology of the chamber 
598 (Spero, 1988). Some species of planktonic foraminifera have micro- instead of macropores

599 (often in species with secondary apertures; Globigerinata glutinata, Candeina nitida), ranging 600 from 0.3-0.7 $\mu \mathrm{m}$ (Brummer and Kroon, 1988). These micropores do not appear to have a pore 601 plate, and their function, formation and morphology is less well understood than those for 602 macropores.

603 as 'ontogenetic' or 'lamellar' calcite (Erez, 2003). Additional $\mathrm{CaCO}_{3}$ can be present as ornamentations (pustules, spines, ridges, tooth plates, etc.) or as layers of calcite covering the whole test (crust or gametogenic (GAM) calcite). Whereas ornamentation is present throughout the entire life cycle of a foraminifer (Hemleben, 1975), GAM calcite is exclusive to planktonic foraminifera and is added after the last chamber is formed and just prior to meiotic division of the nucleus and gametogenesis.

612 In some planktonic species, a calcite crust can be formed after formation of the final chamber 613 (Bé and Ericson, 1963; Bé and Lott, 1964; Bé, 1965; Bé and Hemleben, 1970; Olsson, 1976). 614 The morphology of this calcite is markedly different from that of either ontogenetic or GAM 615 calcite and its element and isotopic composition can differ from that of the ontogenetic calcite 616 because it forms under different environmental conditions of temperature and/or salinity. For 617 instance, crust $\mathrm{Mg} / \mathrm{Ca}$ is generally lower than that of ontogenetic calcite in Globorotalia 618 truncatulinoides (Duckworth, 1977) and Neogloboquadrina dutertrei (Jonkers et al., 2012). These lower element concentrations are partly a consequence of conditions deeper in the water column (i.e. lower temperature), but it should be noticed that the observed partitioning 621 for $\mathrm{Mg}$ indicates that crust calcification is a biologically controlled process. Interestingly, 
622 Nürnberg et al. (1996) found that crusts formed in culture can have a higher $\mathrm{Mg} / \mathrm{Ca}$ than the 623 ontogenetic calcite.

624 In a number of species such as G. sacculifer, gametogenesis is preceded by the production of 625 a layer of calcite covering spine holes and the terrace-like structures of inter-pore rims (Towe 626 and Cifelli, 1967; Bé, 1980; Hemleben et al., 1985; Brummer et al., 1987). This GAM calcite

627 veneer gives the foraminifera a smooth appearance by covering the rough topography of the 628 shell surface and it has been suggested that it is enriched in some trace elements compared to 629 the ontogenetic calcite (Hathorne et al., 2009). Whether this observation holds for all 630 foraminifera forming GAM calcite, however, remains to be investigated.

631 From the perspective of biomineralization, variability in the types of $\mathrm{CaCO}_{3}$ that are formed 632 may indicate that foraminifera do not have one single way to produce shell calcite. Rather, the 633 physiological tools to achieve calcite precipitation as discussed in sections 2 and 4, are likely 634 used in different combinations by different species of foraminifera. Moreover, the variability 635 in calcite within single specimens suggests a degree of flexibility of these physiological tools 636 even within single species. Identification of seawater vacuolization, transmembrane ion 637 transport, nucleation promoting organic templates, etc. across species and their contribution to 638 calcification within a foraminifer's life time are critical aspects of foraminiferal biology and 639 keys to understanding foraminiferal biomineralization from a mechanistic perspective.

\section{Future directions}

642 A complete mechanistic description of foraminiferal biomineralization and chamber formation does not yet exist. Hence, the biological and environmental interplay that controls 644 the element composition and isotope fractionation of chamber calcite is only partly 645 understood. Literature on foraminiferal calcification is both qualitative and quantitative but on 
646 occasion, contradictory. This leaves us with a number of outstanding questions that need to be

647 addressed in order to move this area of foraminifera biology forward. These include:

648

649 1. Which foraminiferal species use vacuolized seawater as the primary source for calcification and which use transmembrane transport of $\mathrm{Ca}^{2+}$ and DIC during calcification? The investigation into the transport of ions to the site of calcification may be solved by answering a number of more practical questions, including:

- What is the relation between transmembrane transport and vaculization on the one hand, and production of intracellular calcium and/ or carbon reservoirs on the other hand?

- What is the biochemical basis of these processes? Which transmembrane transporters are involved (e.g. Ca-ATPases, proton- $\mathrm{Ca}^{2+}$ antiporters)? By which mechanism is inorganic carbon concentrated (e.g. involvement of Carbonic Anhydrase)?

- When characterized, can these (transport) mechanisms explain observed element incorporation and isotopes fractionations. If yes, can these mechanisms explain foraminiferal chemistry for (all) these elements and isotopes at the same time?

- Is there a general difference between planktonic and benthic species in production of vacuolized seawater, internal reservoirs and/or direct ion transport?

- Do foraminifera employ both mechanisms to calcify and if yes, what is the balance between these two pathways?

2. What is the tertiary structure of the organic matrix/ matrices (e.g. POS, organic linings) involved in biomineralization? Which compounds help to lower the free energy barrier, thereby promoting calcite nucleation? When identified, do these organic compounds have an impact on the partition coefficient of elements and fractionation of isotopes at the first stage of chamber formation? 
671

672

673

674

675

676

677

678

679

680

681

682

683

684

685

686

687

688

689

690

691

692

693

694

3. To what extent is the site of calcification in contact with surrounding seawater? If seawater directly contributes (part of) the ions for calcification, can this source explain observed fractionation factors and partition coefficients?

4. What is the role of mitochondria in calcification? Do mitochondria (help to) regulate the $\mathrm{Mg} / \mathrm{Ca}$ at the site of calcification?

Finally, a more detailed understanding of foraminiferal biominiralization will also allow researchers to compare calcification strategies accross marine calcifiers. Compared to foraminifera, biomineralization in corals (Al-Horani et al., 2003; Sinclair and Risk, 2006;

Venn et al., 2013), coccolithophores (Marsh, 2003; Taylor et al., 2011; Ziveri et al., 2012;

Bach et al., 2013), gastropods (e.g. Nehrke et al., 2011) and bivalves (Nudelman et al., 2006;

Nehrke et al., 2012; Shi et al., 2013) are understood in greater detail. Identification of differences and similarities between these marine calcifying taxa will allow studying (convergent) evolutionairy patterns, help to understand differences in their response to (future) environmental perturbations and facilitate comparison of paleoceanographic information obtained across taxa.

\section{Acknowledgements}

Darwin Center, Discussions with Gernot Nehrke (AWI) and Gerald Langer (AWI, Cambridge) greatly helped develop the ideas that are presented in this paper. This paper was the result of research supported by the European Commission through grant 211384 (EU FP7 "EPOCA"), grant 265103 (EU FP7 "MedSeA"), by support through the German Federal Ministry of Education and Research (BIOACID; BMBF, FKZ 03 F0608) and by support of the Darwin Center for Biogeosciences. Howard Spero acknowledges the support of the 
697

698

699

700

701

702

703

704

705

706

707

708

709

710

711

712

713

714

715

716

717

718

Alexander von Humboldt Foundation. Jonathan Erez acknowledges the support of the Israel

Science Foundation grant 551/10.

\section{References}

Al-Horani, F.A., Al-Moghrabi, S.M., De Beer, D., 2003. Microsensor study of photosynthesis and calcification in the scleractinian coral, Galaxea fascicularis: active internal carbon cycle. J. Exp. Mar. Biol. Ecol. 288, 1-15.

Allen, K.A., Hönisch, B., Eggins, S.M., Yu, J., Spero, H.J., Elderfield, H., 2011. Controls on boron incorporation in cultured tests of the planktic foraminifer Orbulina universa. Earth Planet. Sci. Lett. 309, 291-301.

Ambudkar, S.V., Zlotnick, G.W., Rosen, B.P., 1984. Calcium efflux from Escherichia coli. Evidence for two systems. Journal of Biol. Chem. 259, 6142-6146.

Anderson, O.R., Bé, A.W.H., 1976. The ultrastructure of a planktonic foraminifer, Globigerinoides sacculifer (Brady), and its symbiotic dinoflagellates. J. Foramin. Res. $6,1-21$

Anderson, O.R., Faber, W.W. Jr, 1984. An estimation of calcium carbonate deposition rate in a planktic foraminifer Globigerinoides sacculifer using ${ }^{45} \mathrm{Ca}$ as a tracer: a recommended procedure for improved accuracy. J. Foramin. Res. 14, 303-308.

Angell, R.W., 1979. Calcification during chamber development in Rosalina floridana. J. Foramin. Res. 9, 341-353.

Bach, L.T., Mackinder, L.C.M., Schultz, K.G., Wheeler, G., Schroeder, D.C., Brownlee, C., Riebesell, U., 2013. Dissecting the impact of $\mathrm{CO}_{2}$ and $\mathrm{pH}$ on the mechanisms of photosynthesis and calcification in the coccolithophore Emiliania huxleyi. New Phytol. $199,121-134$ 
Banner, F.T., Sheehan, R., Williams, E., 1973. The organic skeletons of rotaline foraminifera: A review. J. Foramin. Res. 3, 30-42.

Bé, A.W.H., Ericson, D.B., 1963. Aspects of calcification in planktonic foraminifera (Sarcodina). New York Acad. Sci., Ann., vol. 109, art. 1, pp. 65-81.

Bé, A.W.H., Lott, L., 1964. Shell growth and structure of planktonic foraminifera. Science $145,823-824$.

Bé, A.W.H., 1965. The influence of depth on shell growth in Globigerinoides sacculifer (Brady). Micropaleontology 11, 81-97.

Bé, A.W.H., 1980. Gametogenic calcification in a spinose planktonic foraminifer, Globigerinoides sacculifer (Brady). Mar. Micropaleontol. 5, 283-310.

Bé, A.W.H., Hemleben, C., 1970. Calcification in a living planktonic foraminifer, Globigerinoides sacculifer (Brady). N. Jb. Geol. Paläont. Abh. 134, 221-234.

Bé, A.W.H., Hemleben, C., Anderson, O.R., Spindler, M., Hacunda, J., Tunitivate-Choy, S., 1977. Laboratory and field observation of living planktonic foraminifera. Micropaleontology 23, 155-179.

Bé, A.W.H., Hemleben, C., Anderson, O.R., Spindler, M., 1979. Chamber formation in planktic foraminifera. Micropaleontology 25, 294-307.

Bé, A.W.H., Spero, H.J., Anderson, O.R., 1982. Effects of symbiont elimination and reinfection on the life processes of the planktonic foraminifer Globigerinoides sacculifer. Mar. Biol, 70, 73-86.

Bender, M.L., Lorens, R.B., Williams, D.F., 1975. Sodium, magnesium and strontium in the tests of planktonic foraminifera. Micropaleontology 21, 448-459.

Bentov, S., Erez, J., 2005. Novel observations on biomineralization processes in foraminifera and implications for $\mathrm{Mg} / \mathrm{Ca}$ ratio in the shells. Geology 33, 841-844. 
Bentov, S., Erez, J., 2006. Impact of biomineralization process on the Mg content of foraminiferal shells: A biological perspective. Geochem. Geophy. Geosy. 7, doi:10.1029/2005GC001015.

Bentov, S., Brownlee, C., Erez, J., 2009. The role of seawater endocytosis in the biomineralization process in calcareous foraminifera. P. Natl. Acad. Sci. USA 106, 21500-21504.

Berthold, W.U., 1976. Ultrastructure and function of wall perforations in Patellina corrugate Williamson, Foraminifera. J. Foramin. Res. 6, 22-29.

Bijma, J., Spero, H.J., Lea, D.W., 1999. Reassessing foraminiferal stable isotope geochemistry: Impact of the oceanic carbonate system (experimental results). Use of Proxies in Paleoceanography: Examples from the South Atlantic. G. Fischer and G. Wefer. Berlin, Heidelberg, Springer-Verlag: 489-512.

Boyle, E., 1981. Cadmium, zinc, copper, and barium in foraminiferal tests. Earth Planet. Sci. Lett. 53, 11-35.

Brummer, G.J., Hemleben, C., Spindler, M., 1987. Ontogeny of extant spinose planktonic foraminifera (Globigerinidae): a concept exemplified by Globigerinoides sacculifer (Brady) and G. ruber (D'Orbigny). Mar. Micropaleontol. 12, 357-381.

Brummer, G.J.A., Kroon, D., 1988. Planktonic foraminifers as tracers of ocean-climate history. Free University Press, Amsterdam, 346 pp.

Carafoli, E., Santella, L., Branca, D., Brini, M., 2001. Generation, control, and processing of cellular calcium signals. Crit. Rev. Biochem. Mol. 36, 107-260.

Caron, D.A., Bé, A.W.H., Anderson, O.R., 1982. Effects of variations in light intensity on life processes of the planktonic foraminifer Globigerinoides sacculifer in laboratory culture. J. Mar. Biol. Assoc. UK 62, 435-451. 
767 De Nooijer, L.J., Toyofuku, T., Kitazato, H., 2009a. Foraminifera promote calcification by 768 elevating their intracellular pH. P. Natl. Acad. Sci. USA 106, 15374-15378.

769 De Nooijer, L.J., Langer, G., Nehrke, G., Bijma, J., 2009b. Physiological controls on the seawater uptake and calcification in the benthic foraminifer Ammonia tepida. Biogeosciences 6, 2669-2675.

De Yoreo, J.J., Velikov, P.G., 2003. Principles of crystal nucleation and growth. Rev. Mineral. Geochem. 54, 57-94.

774

775

776

777

778

779

DePaolo, D.J., 2011. Surface kinetic model for isotopic and trace element fractionation during precipitation of calcite from aqueous solution. Geochim. Cosmochim. Ac. 75, 10391056.

Dissard, D., Nehrke, G., Reichart, G.J., Bijma, J., 2010. Impact of seawater $p \mathrm{CO}_{2}$ on calcification and $\mathrm{Mg} / \mathrm{Ca}$ and $\mathrm{Sr} / \mathrm{Ca}$ ratios in benthic foraminiferal calcite: results from culturing experiments with Ammonia tepida. Biogeosciences 7, 81-93.

Dove, P.M., De Yoreo, J.J., Weiner, S., 2003. Biomineralization: Reviews in Mineralogy and Geochemistry 54, Mineralogical Society of America. Washington DC, $381 \mathrm{pp}$.

Drake, S.K., Lee, K.L., Falke, J.J., 1996. Tuning the equilibrium ion affinity and selectivity of the EF-Hand calcium binding motif: Substitutions at the gateway position. Biochem 35, 6697-6705.

Duckworth, D.L., 1977. Magnesium concentration in the tests of the planktonic foraminifer Globorotalia truncatulinoides. J. Foramin. Res. 7, 304-312.

Dueñas-Bohórquez, A., Raitzsch, M., De Nooijer, L.J., Reichart, G.J., 2010. Independent impacts of calcium and carbonate ion concentration on $\mathrm{Mg}$ and $\mathrm{Sr}$ incorporation in cultured benthic foraminifera. Mar. Micropaleontol, 81, 122-130. 
Eggins, S.M., Sadekov, A., De Deckker, P., 2004. Modulation and daily banding of Mg/Ca in Orbulina universa tests by symbiont photosynthesis and respiration: a complication for seawater thermometry? Earth Planet. Sci. Lett. 225, 411-419.

Elderfield, H., Bertram, C.J., Erez, J., 1996. A biomineralization model for the incorporation of trace elements into foraminiferal calcium carbonate. Earth Planet. Sci. Lett. 142, 409423.

Epstein, S., Buchsbaum, R., Lowenstam, H., Urey, H.C., 1951. Carbonate-water isotopic temperature scale. Bull. Geol. Soc. Am. 62, 417-426.

Erez, J., 1978. Vital effect on stable-isotope composition seen in foraminifera and coral skeletons. Nature 273, 199-202.

Erez, J., 1983. Calcification rates, photosynthesis and light in planktonic foraminifera. In: P. Westbroek, E.W. de Jong (eds), Biomineralization and biological metal accumulation. Reidel Publishing Company. 307-312.

Erez, J., 2003. The source of ions for biomineralization in foraminifera and their implications for paleoceanographic proxies. Rev. Mineral. Geochem. 54, 115-149.

Glas, M., Langer, G., Keul, N., 2012. Calcification acidifies the microenvironment of a benthic foraminifer (Ammonia sp.). J. Exp. Mar. Biol. Ecol. 424-425, 53-58.

Gouaux, E., MicKinnon, R., 2005. Principles of selective ion transport in channels and pumps. Science 310, 1461-1465.

Gonçalves, P.P., Meireles, S.M., Gravato, C., Vale, M.G.P., 1998. $\mathrm{Ca}^{2+}-\mathrm{H}^{+}$-antiport activity in synaptic vesicles isolated from sheep brain cortex. Neurosci. Lett. 247, 87-90.

Gonçalves, P.P., Meireles, S.M., Neves, P., Vales, M.G.P., 1999. Ion selectivity of the $\mathrm{Ca}^{2+} / \mathrm{H}^{+}$antiport in synaptic vesicles of sheep brain cortex. Mol. Brain Res. 67, 283-291.

Grossman, E.L., 1987. Stable isotopes in modern benthic foraminifera: A study of vital effect. J. Foramin. Res. 17, 48-61. 
815 Gussone, N., Eisenhauer, A., Heuser, A., Dietzel, M., Bock, B., Böhm, F., Spero, H.J., Lea, 816 D.W., Bijma, J., Nägler, T.F., 2003. Model for kinetic effects on calcium isotope 817 fractionation $\left(\delta^{44} \mathrm{Ca}\right)$ in inorganic aragonite and cultured planktonic foraminifera. 818 Geochim. Cosmochim. Ac. 67, 1375-1382.

819 Hamilton, C.P., Spero, H.J., Bijma, J., Lea, D.W., 2008. Geochemical investigation of 820 gametogenic calcite addition in the planktonic foraminifera Orbulina universa. Mar. $821 \quad$ Micropaleontol. 68, 256-267.

822 Hastings, D.W., Russell, A.D., Emerson, S.R., 1998. Foraminiferal magnesium in 823 Globigerinoides sacculifer as a paleotemperature proxy. Paleoceanography 13, 161-169.

824 Hathorne, E.C., James, R.H., Lampitt, R.S., 2009. Environmental versus biomineralization 825 controls on the intratest variation in the trace element composition of the planktonic

Hemleben, C., 1975. Spine and pustule relationships in some recent planktonic foraminifers. Micropaleontology 21, 334-341.

Hemleben, C., Bé, A.W.H., Anderson, O.R., Tuntivate, S., 1977. Test morphology, organic layers and chamber formation in the planktonic foraminifer Globorotalia menardii (d'Orbigny). J. Foramin. Res. 7, 1-25.

Hemleben, C., Spindler, M., Breitinger, I., Deuser, WG., 1985. Field and laboratory studies on the ontogeny and ecology of some Globorotaliid species from the Sargasso Sea off Bermuda. J. Foramin. Res. 15, 254-272.

Hemleben, C., Anderson, O.R., Berthold, W., Spindler, M., 1986. Calcification and chamber formation in Foraminifera - a brief overview. In: Leadbeater BS, Riding R (eds), The systematics association, special volume $30,237-249$. 
839 Hemleben, C., M. Spindler, Anderson, O.R., 1989. Modern planktonic foraminifera. New $840 \quad$ York, Springer, 363 pp.

841 Hemleben, C., Mühlen, D., Olsson, R.K., Berggren, W.A., 1991. Surface texture and first 842 occurrence of spines in planktonic foraminifera from the early Tertiary. Geologisches $843 \quad$ Jahrbuch A 128, 117-146.

844 Hemleben, C., Bijma, J., 1994. Foraminiferal population dynamics and stable carbon isotopes. $845 \quad$ NATO ASI series $117,145-166$.

846 Higgins, C.F., 1992. ABC transporters: from microorganisms to man. Annu. Rev. Cell Biol. 8, 67-113.

Hönisch, B., Allen, K.A., Lea, D.W., Spero, H.J., Eggins, S.M., Arbuszewski, J., deMenocal, 849 P., Rosenthal, Y., Russell, A.D., Elderfield, H., 2013. The influence of salinity on $\mathrm{Mg} / \mathrm{Ca}$ in planktic foraminifers - Evidence from cultures, core-top sediments and complementary $\delta^{18}$ O. Geochim. Cosmochim. Acta 121, 196-213.

Hottinger, L., Dreher, D., 1974. Differentiation of protoplasm in Nummulitidae (Foraminifera) from Elat, Red Sea. Mar. Biol. 25, 41-61.

Ishikawa, M., Ichikuni, M., 1984. Uptake of sodium and potassium by calcite. Chem. Geol. $42,137-146$

Jørgensen, B.B., Erez, J., Revsbech, N.P., Cohen, Y., 1985. Symbiotic photosynthesis in a planktonic foraminiferan Globigerinoides sacculifer (Brady), studied with microelectrodes. Limnol. Oceonogr. 30, 1253-1267.

Katz, A., 1973. The interaction of magnesium with calcite during crystal growth at $25-90^{\circ} \mathrm{C}$ and one atmosphere. Geochim. Cosmochim. Ac. 37, 1563-1586.

Katz, M.E., Cramer, B.S., Franzese, A., Hönisch, B., Miller, K.G., Rosenthal, Y., Wright, J.D., 2010. Traditional and Emerging geochemical proxies in foraminifera. J. Foramin. Res. 40, 165-192. 
King, K., Hare, P.E., 1972. Amino acid composition of the test as a taxonomic character of living and fossil planktonic foraminifera. Micropaleonontology 18, 285-293.

Kitano, Y., Okumura, M., Idogaki, M., 1975. Incorporation of sodium, chloride and sulfate with calcium carbonate. Geochem. J. 9, 75-84.

Kitazato, H., Bernhard J.M., 2014.Approaches to study living foraminifera: collection, maintainance and experimentation. Springer, $227 \mathrm{pp}$.

Köhler-Rink, S., Kühl, M., 2000. Microsensor studies of photosynthesis and respiration in larger symbiotic foraminifera. I The physico-chemical microenvironment of Marginopora vertebralis, Amphistegina lobifera and Amphisorus hemprichii. Mar. Biol. $137,473-486$.

Köhler-Rink, S., Kühl, M., 2005. The chemical microenvironment of the symbiotic planktonic foraminifer Orbulina universa. Mar. Biol. Res. 1, 68-78.

Kozdon, R., Ushikubo, T., Kita, N.T., Spicuzza, M., Valley, J.W., 2009. Intratest oxygen isotope variability in the planktonic foraminifer $N$. pachyderma: real vs. apparent vital effects by ion microprobe. Chem. Geol. 258, 327-337.

Kunioka, D., Shirai, K., Takahata, N., Sano, Y., Toyofuku, T., Ujiie, Y., 2006. Microdistribution of $\mathrm{Mg} / \mathrm{Ca}, \mathrm{Sr} / \mathrm{Ca}$, and $\mathrm{Ba} / \mathrm{Ca}$ ratios in Pulleniatina obliquiloculata test by using a NanoSIMS: Implication for the vital effect mechanism. Geochem. Geophy. Geosy. 7, doi: 10.1029/2006GC001280.

Langer, M.R., 1992. Biosynthesis of glycosaminoglycans in foraminifera: A review. Marine Micropaleontology 19, 245-255.

Lea, D.W., Boyle, E.A., 1991. Barium in planktonic foraminifera. Geochim. Cosmochim. Ac. $55,3321-3331$. 
887 Lea, D.W., Spero, H.J., 1992. Experimental determination of barium uptake in shells of the planktonic foraminifera Orbulina universa at $22^{\circ} \mathrm{C}$. Geochim. Cosmochim. Ac. 56, 2673-2680.

890

891

892

Lea, D.W., Martin, P.A., Chan, D.A., Spero, H.J., 1995. Calcium uptake and calcification ratae in planktonic foraminifer Orbulina universa. J. Foramin. Res. 25, 14-23.

Lea, D.W., Mashoitta, T.A., Spero, H.J., 1999. Controls on magnesium and strontium uptake in planktonic foraminifera determined by live culturing. Geochim. Cosmochim. Ac. 63, 2369-2379.

Lea, D.W., Pak, D.K., Spero, H.J., 2000. Climate impact of late Quaternary equatorial Pacific sea surface temperature variations. Science 289, 1719-1724.

Lear, C.H., Elderfield, H., Wilson, P.A., 2000. Cenozoic deep-sea temperatures and global ice volumes from $\mathrm{Mg} / \mathrm{Ca}$ ratios in benthic foraminiferal calcite. Science 287, 269-272.

Lee, J.J., Anderson, O.R. (eds), 1991. Biology of Foraminifera, Academic Press, London, 368 pp.

Lehninger, A.L., Rossi, C.S., Greenawalt, J.W., 1963. Respiration-dependent accumulation of inorganic phosphate and $\mathrm{Ca}^{2+}$ by rat liver mitochondria. Biochem. Biophy. Res. Comm. $10,444-448$.

Lowenstam, H.A., Weiner, S., 1989. Biomineralization. Oxford University Press. pp xxx.

Mann, S., 1988. Molecular recognition in biomineralization. Nature 332, 119-124.

Marriott, C.S., Henderson, G.M., Belshaw, N.S., Tudhope, A.W., 2004. Temperature dependence of $\delta^{7} \mathrm{Li}, \delta^{44} \mathrm{Ca}$ and $\mathrm{Li} / \mathrm{Ca}$ during growth of calcium carbonate. Earth Planet. Sci. Lett. 222, 615-624.

Marsh, M.E., 2003. Regulation of $\mathrm{CaCO}_{3}$ formation in coccolithophores. Comp. Biochem. Physiol. B. Biochem. Mol. Biol. 236,743-754. 
911 McConnaughey, T.A., Whelan, J.F., 1997. Calcification generates protons for nutrient and 912 bicarbonate uptake. Earth-Sci. Rev. 42, 95-117.

913 McCrea, J.M., 1950. On the isotopic chemistry of carbonates and a paleotemperature scale. J. $914 \quad$ Chem. Phys. 18, 849-857.

915 Morse, J.W., Arvidson, R.S., Lüttge, A., 2007. Calcium carbonate formation and dissolution. $916 \quad$ Chem. Rev. 107, 342-381.

917 Morse, J.W., Bender, M.L., 1990. Partition coefficients in calcite: Examination of factors 918 influencing the validity of experimental results and their application to natural systems. $919 \quad$ Chem. Geol. 82, 265-277.

920 Mucci, A., 1987. Influence of temperature on the composition of magnesian calcite 921 overgrowths precipitated from seawater. Geochim. Cosmochim. Ac. 51, 1977-1984.

922 Nehrke, G., Nouet, J., 2011. Confocal Raman microscope mapping as a tool to describe 923 different mineral phases at high spatial resolution within marine biogenic carbonates: a 924 case study on Nerita undata (Gastropoda, Neritopsina). Biogeosciences 8, 3761-3769.

925 Nehrke, G., Poigner, H., Wilhelms-Dick, D., Brey, T., Abele, D., 2012. Coexistence of three 926 calcium carbonate polymorphs in the shell of the Antarctic clam Laternula elliptica. 927 Geochem. Geophys. Geosys. 13, Q05014.

928 Nehrke, G., Keul, N., Langer, G., De Nooijer,. L.J., Bijma, J., 2013. A new model for 929 biomineralization and trace-element signatures of Foraminifera tests. Biogeosciences 10, $930 \quad 6759-6767$.

931 Nudelman, F., Gotliv, B.A., Addadi, L., Weiner, S., 2006. Molusk shell formation: mapping 932 the distribution of organic matrix components underlying a single aragonitic tablet in 933 nacre. J. Struc. Biol. 153, 176-178. 
934 Nürnberg, D., Bijma, J., Hemleben, C., 1996. Assessing the reliability of magnesium in 935 foraminiferal calcite as a proxy for water mass temperature. Geochim. Cosmochim. Ac. $936 \quad 60,803-814$.

937 Ogawa, T., Kaplan, A., 1987. The stoichiometry between $\mathrm{CO}_{2}$ and $\mathrm{H}^{+}$fluxes involved in the 938 transport of inorganic carbon in cyanobacteria. Plant Physiol. 83, 888-891.

939 Olsson, R.K., 1976. Wall structure, topography and crust of Globigerina pachyderma 940 (Ehrenberg). Progress in Micropaleontology: 1-9.

941 Pereira, A.C., Samellas, D., Tiffert, T., Lew, V.L., 1993. Inhibition of the calcium pump by high cytosolic $\mathrm{Ca}^{2+}$ in intact human red blood cells. J. Physiol. 461, 63-73.

943 Pingitore, N.E., Eastman, M.P., 1984. The experimental partitioning of $\mathrm{Ba}^{2+}$ into calcite. $944 \quad$ Chem. Geol. 45, 113-120.

945 Raz, S., Weiner, S., Addadi, L., 2000. Formation of high-magnesian calcites via an 946 amorphous precursor phase: possible biological implications. Adv. Mater. 12, 38-42.

947 Reiss, Z., 1957. The Bilamellidea, nov. superfam., and remarks on Creteceous globorotaliids. 948 Cushman Foundation Foramin. Res. Contr. 8, 127-145.

949 Reiss, Z., 1960. Structure of so-called Eponides and some other Rotaliiform Foraminifera. 950 Ministry of Development Geological Survey 29, 1-29.

951 Rickaby, R.E.M., Elderfield, H., 1999. Planktonic foraminiferal Cd/Ca: paleonutrients or 952 paleotemperature? Paleoceanography 14, 293-303.

953 Rimstidt, D.J., Balog, A., Webb, J., 1998. Distribution of trace elements between carbonate 954 minerals and aqueous solutions. Geochim. Cosmochim. Ac. 62, 1851-1863.

955 Rink, S., Kühl, M., Bijma, J., Spero, H.J., 1998. Microsensor studies of photosynthesis and 956 respiration in the symbiotic foraminifer Orbulina universa. Mar. Biol. 131, 583-595.

957 Robbins, L.L., Brew, K., 1990. Proteins from the organic matrix of core-top and fossil 958 planktonic foraminifera. Geochim. Cosmochim. Ac. 54, 2285-2292. 
Robbins, L.L., Healy-Williams, N.H., 1991. Toward a classification of planktonic foraminifera based on biochemical, geochemical, and morphological criteria. J. Foramin. Res. 21, 159-167.

Saito, T., Thompson, P.R., Breger, D., 1976. Skeletal ultra-microstructure of some elongatechambered planktonic Foraminifera and related species. In: Takayanagi Y, Saito T (eds), Selected papers in honor of Prof. Kiyoshi Asano. Progress in Micropaleontology Special Publication, 278-304.

Schmiedl, G., Mackensen, A., 2006. Multispecies stable isotopes of benthic foraminifers reveal past changes of organic matter decomposition and deep water oxygenation in the Arabian Sea. Paleoceanography 21, PA4213.

Segev, E., Erez, J., 2006. Effect of $\mathrm{Mg} / \mathrm{Ca}$ ratio in seawater on shell composition in shallow benthic foraminifera. Geochem. Geophy. Geosy. 7: Q02P09.

Shi, Y., Yu, C., Gu, Z., Zhan, X., Wang, Y., Wang, A., 2013. Characterization of the pearl oyster (Pinctada martensii) mantle transcriptome unravels biomineralization genes. Mar. Biotechnol. 15, 175-187.

Sinclair, D., Risk, M., 2006. A numerical model of trace element coprecipitation in a physicochemical calcification system: Application to coral biomineralization and trace element vital effects. Geochim. Cosmochim. Ac. 70, 3855-3868.

Spero, H.J., 1988. Ultrastructural examination of chamber morphogenesis and biomineralization in the planktonic foraminifer Orbulina universa. Mar. Biol. 99, 9-20.

Spero, H.J., Bijma, J., Lea, D.W., Bemis, B.E., 1997. Effect of seawater carbonate concentration on foraminiferal carbon and oxygen isotopes. Nature 390, 497-500.

Spindler, M., 1978. The development of the organic lining in Heterostegina depressa (Nummulitidae: Foraminifera). J. Foramin. Res. 8, 258-261. 
Tang, J., Niedermayr, A., Köhler, S.J., Böhm, F., Kisakürek, B., Eisenhauer, A., Dietzel, M., 2012. $\mathrm{Sr}^{2+} / \mathrm{Ca}^{2+}$ and ${ }^{44} \mathrm{Ca} /{ }^{40} \mathrm{Ca}$ fractionation during inorganic calcite formation: III. Impact of salinity/ ionic strength. Geochim. Cosmochim. Ac. 77, 432-443.

Taylor, A.R., Chrachri, A., Wheeler, G., Goddard, H., Brownlee, C., 2011. A voltage-gated $\mathrm{H}+$ channel underlying $\mathrm{pH}$ homeostasis in calcifying coccolithophores. PLoS Biol. 9: e1001085.

Ter Kuile, B., Erez, J., 1984. In situ growth rate experiments on the symbiont-bearing foraminifera Amphistegina lobifera and Amphisorus hemprichii. J. Foramin. Res. 14, 262-276.

Ter Kuile, B., Erez, J., 1987. Uptake of inorganic carbon and internal carbon cycling in symbiont-bearing benthonic foraminifera. Mar. Biol. 94, 499-509.

Ter Kuile, B., Erez, J., 1988. The size and function of the internal inorganic carbon pool of the foraminifer Amphistegina lobifera. Mar. Biol. 99, 481-487.

Ter Kuile, B., Erez, J., Padan, E., 1989a. Competition for inorganic carbon between photosynthesis and calcification in the symbiont-bearing foraminifer Amphistegina lobifera. Mar. Biol. 103, 253-259.

Ter Kuile, B., Erez, J., Padan, E., 1989b. Mechanisms for the uptake of inorganic carbon by two species of symbiont-bearing foraminifera. Mar. Biol. 103, 241-251.

Ter Kuile, B., Erez, J., 1991. Carbon budgets for two species of benthonic symbiont-bearing foraminifera. Biol. Bull. 180, 489-495.

Terakado, Y., Ofuka, Y., Tada, N., 2010. Rare earth elements, Sr, Ba, Fe, and major cation concentrations in some living foraminiferal tests collected from Iriomote Island, Japan: An exploration for trace element behavior during biogenic calcium carbonate formation. Geochem. J. 44, 315-322. 
1007

1008

1009

1010

1011

1012

1013

1014

1015

1016

1017

1018

1019

1020

1021

1022

1023

1024

1025

1026

1027

1028

1029

1030

1031

Towe, K.M., Cifelli, R., 1967. Wall ultrastructure in the calcareous Foraminifera: crystallographic aspects and a model for calcification. J. Paleontol. 41, 742-762.

Toyofuku, T., De Nooijer, L.J., Yamamoto, H., Kitazato, H., 2008. Real-time visualization of calcium ion activity in shallow benthic foraminiferal cells using the fluorescent indicator Fluo-3 AM. Geochem. Geophy. Geosy. 9, Q05005, doi: 10.1029/2007GC001772.

Urey, H.C., Lowenstam, H.A., Epstein, S., McKinney, C.R., 1951. Measurement of paleotemperatures and temperatures of the upper Cretaceous of England, Denmark, and the Southeastern United States. Bull. Geol. Soc. Am. 62, 399-416.

Venn, A.A., Tambutté, E., Holcomb, M., Laurent, J., Allemand, D., Tambuté, S., 2013. Impact of seawater acidification on $\mathrm{pH}$ at the site of tissue-skeleton interface and calcification in reef corals. P. Natl. Acad. Sci. USA 110, 1634-1639.

Vetter, L., Kozdon, R., Mora, C.I., Eggins, S.M., Valley, J.W., Hönisch, B., Spero, H.J., 2013. Micron-scale intrashell oxygen isotope variation in cultured planktic foraminifers. Geochim. Cosmochim. Ac. 107, 1-12.

Wang, K.K.W., Villalobo, A., Roufogalis, B.D., 1992. The plasma membrane calcium pump: a multiregulated tranporter. Trends Cell Biol. 2, 46-52.

Weiner, S., Dove, P.M., 2003. An overview of biomineralization processes and the problem of the vital effect. Rev. Mineral. Geochem. 54, 1-29.

Weiner, S., Erez, J., 1984. Organic matrix of the shell of the foraminifer, Heterostegina depressa. J. Foramin. Res. 14, 206-212.

Wetmore, K., 1999. Chamber formation in Archaias ungulatus. J. Foramin. Res. 29, 69-74.

Wilson, J.E., Chin, A., 1991. Chelation of divalent cations by ATP, studied by titration calorimetry. Anal. Biochem. 193, 16-19.

Wolf-Gladrow, D., Bijma, J., Zeebe, R.E., 1999. Model simulation of the carbonate system in the microenvironment of symbiont bearing foraminifera. Mar. Chem. 64, 181-198. 
Zeebe, R.E., 1999. An explanation of the effect of seawater carbonate concentration on foraminiferal oxygen isotopes. Geochim. Cosmochim. Ac. 63, 2001-2007.

Zeebe, R.E., Bijma, J., Wolf-Gladrow, D.A., 1999. A diffusion-reaction model of carbon isotope fractionation in foraminifera. Mar. Chem. 64, 199-227.

Zeebe, R.E., Sanyal, A., 2002. Comparison of two potential strategies of planktonic foraminifera for house building: $\mathrm{Mg}^{2+}$ or $\mathrm{H}^{+}$removal? Geochim. Cosmochim. Ac. 66, 159-169.

Zeebe, R.E., Bijma, J., Hönisch, B., Sanyal, A., Spero, H.J., Wolf-Gladrow, D.A., 2008. Vital effects and beyond: a modeling perspective on developing palaeoceanographical proxy relationships in foraminifera. Geol. Soc., London Special Publications 303, 45-58.

Ziveri, P., Thoms, S., Probert, I., Geisen, M., Langer, G., 2012. A universal carbonate ion effect on stable oxygen isotope ratios in unicellular planktonic calcifying organisms. Biogeosciences 9, 1025-1032. 


\section{Biomineralization in perforate Foraminifera}

2

3 LJ de Nooijer ${ }^{\mathrm{a}, *}$, HJ Spero $^{\mathrm{b}}, \mathrm{J} \mathrm{Erez}^{\mathrm{c}}, \mathrm{J} \mathrm{Bijma}^{\mathrm{d}}$, GJ Reichart $^{\mathrm{a}, \mathrm{e}}$

4

5 a Department of Marine Geology, Royal Netherlands Institute for Sea Research, Landsdiep 4,

${ }^{\mathrm{b}}$ Department of Earth and Planetary Sciences, University of California Davis, Davis, CA 95616, United States of America. hjspero@ucdavis.edu

'Institute of Earth Sciences, The Hebrew University of Jerusalem, Jerusalem 91904, Israel. jonathan.erez@mail.huji.ac.il

${ }^{\mathrm{d}}$ Alfred Wegener Institute for Polar and Marine Research, Am Handelshafen 12, Bremerhaven 27570, Germany.jelle.bijma@awi.de

e Department of Geochemistry, Utrecht University, Budapestlaan 4, 3584 CD Utrecht, The Netherlands. gert-jan.reichart@,nioz.nl

\section{*Corresponding author}

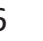




\section{Abstract}

In this paper, we review the current understanding of biomineralization in Rotaliid foraminifera. Ideas on the mechanisms responsible for the flux of $\mathrm{Ca}^{2+}$ and inorganic carbon from seawater into the test were originally based on light and electron microscopic observations of calcifying foraminifera. From the 1980's onward, tracer experiments, fluorescent microscopy and high-resolution test geochemical analysis have added to existing calcification models. Despite recent insights, no general consensus on the physiological basis of foraminiferal biomineralization exists. Current models include seawater vacuolization, transmembrane ion transport, involvement of organic matrices and/or $\mathrm{pH}$ regulation, although the magnitude of these controls remain to be quantified. Disagreement between currently available models may be caused by use of different foraminiferal species as subject for biomineralization experiments and/ or lack of a more systematic approach to study (dis)similarities between taxa. In order to understand foraminiferal controls on element incorporation and isotope fractionation, and thereby improve the value of foraminifera as paleoceanographic proxies, it is necessary to identify key processes in foraminiferal biomineralization and formulate hypotheses regarding the involved physiological pathways to provide directions for future research.

\section{Introduction}

All foraminifera make tests although a number of different materials are used in their construction. The 'naked' foraminifera produce tests from organic matter, agglutinated foraminifera use sediment grains as building blocks and calcifying foraminifera use constituents dissolved in seawater to secrete calcium carbonate. Formation of $\mathrm{CaCO}_{3}$ tests plays a significant role in ocean biogeochemical cycles and, more importantly, the fossil remains of calcifying foraminifera are widely used to reconstruct past ocean chemistry and 
environmental conditions. Elemental and isotopic composition of foraminiferal calcite depends on a variety of environmental parameters such as temperature, salinity, $\mathrm{pH}$ and ion concentration (McCrea et al., 1950; Epstein et al., 1951; Boyle, 1981; Nürnberg et al., 1996). These physical and chemical variations are the foundation for developing geochemical proxies that quantify environmental changes through time (see Wefer et al., 1999; Zeebe et al., 2008; Katz et al., 2010 for reviews). For example, the magnesium concentration in foraminiferal calcite $\left(\mathrm{Mg} / \mathrm{Ca}_{\text {calcite }}\right)$ varies primarily with seawater temperature (Nürnberg et al., 1996; Lea et al., 1999; Hönisch et al., 2013) and can be used to reconstruct past sea surface (Hastings et al., 1998; Lea et al., 2000) and deep-water (Lear et al., 2000) temperatures. Reliable application of these proxies requires calibration over a wide range of environmental conditions as well as a thorough understanding of the physiological parameters influencing test formation.

Studies calibrating foraminiferal test composition based on core-tops and controlled growth experiments show that both the chemical and isotopic compositions of these tests are not in equilibrium as defined by inorganic precipitation experiments (Lowenstam and Weiner, 1989; Dove et al., 2003). Microenvironmental controls related to foraminifera physiology have been implicated to explain disequilibrium fractionation in test chemistry (Figure 1). Most foraminiferal species incorporate $\mathrm{Mg}$ with one to two orders of magnitude lower concentration compared to non-biologically precipitated calcium carbonate (Bentov and Erez, 2006; Katz, 1973; Bender et al., 1975). The concentration of barium, on the other hand, is $\sim 10$ times higher in foraminiferal calcite (Lea and Boyle, 1991; Lea and Spero, 1992) compared to inorganic precipitation results (Pingitore and Eastman, 1984). Additionally, elemental concentrations between foraminiferal species can vary by several orders of magnitude (up to two orders of magnitude for Mg; Bentov and Erez, 2006). The biological controls on element 
incorporation and isotope fractionation that cause these offsets are often summarized as 'the vital effect' (Urey et al., 1951; Weiner and Dove, 2003).

Figure 1: Minor and trace element composition of foraminiferal (left) and inorganically precipitated (right) calcite precipitated from seawater (middle). Concentrations are qualitative as they differ between foraminiferal species and depend on environmental conditions. Precipitation rates, ionic strength of the medium and presence of organic compounds are also known to affect partition coefficients. All values are in parts per million (ppm) and based on data in Kitano et al. (1975), Ishikawa and Ichikuni (1984), Rimstidt et al. (1998), Marriott et al. (2004), Morse et al. (2007), Tang et al. (2012) He et al. (2013) for inorganically precipitated calcium carbonates, and Lea and Boyle (1991), Rickaby and Elderfield (1999), Segev and Erez (2006), Terakado et al. (2010), Allen et al. (2011) for foraminiferal calcite composition.

Vital effects comprise 1) chemical alterations of the foraminifers' microenvironment due to physiological processes, 2) cellular controls on the composition of the fluid from which calcite is precipitated and 3) controls on nucleation and crystal growth (e.g. by presence of organic templates). Foraminiferal respiration and/or photosynthesis by symbiotic algae alter the foraminiferal microenvironment chemistry and thereby the conditions in which foraminiferal tests mineralize. Because habitat depth differences in the water column (planktonic species) or migration in the sediment and attachment to plant leaves (benthic species) also modify the calcification environment, these ecological factors are sometimes regarded as being part of the vital effect as well (e.g. Schmiedl and Mackensen, 2006). Ecology-based variability in element incorporation, however, can be accounted for when habitat preferences of foraminiferal species are known. Hence, the term "vital effects" should 
only be used when discussing foraminiferal cellular processes that alter the chemistry of the microenvironment during test mineralization.

To understand the physiological impact on element incorporation and isotope fractionation, the (intra)cellular mechanisms which foraminifera employ to precipitate test $\mathrm{CaCO}_{3}$ must be identified. Biogeochemical mechanisms are involved in regulating concentrations of ions and/or their activity at the site of calcification. Calcification from seawater can be promoted using different mechanisms. Hence, multiple mechanisms have been proposed to explain test calcification, including endocytosis of seawater, transmembrane ion transporters, ion-specific organic templates, production of a privileged space and mitochondrial activity (Spero, 1988; Erez, 2003; Bentov and Erez, 2006; Bentov et al., 2009).

A process-based framework for both inorganic and organismal control of foraminiferal test formation is crucial for the development, calibration and application of geochemical proxies in the geological record. At the same time, a mechanistic understanding of foraminiferal biomineralization will also permit researchers to better interpret data from the fossil record as well as predicting the response of foraminiferal calcification to future environmental changes such as ongoing ocean acidification. Most of the initial observations of chamber formation and calcification in planktonic foraminifera were published during the early period of planktonic foraminifera culturing (e.g. Bé et al., 1977). Highlights of those observations can be found summarized in the seminal text on "Modern Planktonic Foraminifera" (Hemleben et al., 1989). More recently, studying living specimens under controlled conditions (e.g. Kitazato and Bernard, 2014) has further propelled our understanding of foraminiferal growth, reproduction and calcification.

Recent hypotheses on foraminiferal biomineralization are based mainly on experiments with benthic species and although these ideas have to be tested for planktonic species, we will also include the latter group in our discussion. Although a general model for foraminiferal 
biomineralization is still lacking, and it is not yet clear that a single model fits all groups of foraminifera, details on the underlying mechanisms in different species have accumulated and are described here in the context of previously published biomineralization models.

\section{Ions for calcification}

\subsection{Seawater as the direct source for $\mathrm{Ca}^{2+}$ and DIC}

Foraminifera calcify by creating a microenvironment supersaturated with respect to $\mathrm{CaCO}_{3}$, while overcoming inhibition by crystallization inhibitors such as $\mathrm{Mg}^{2+}$. Hence, calcification requires a tight control on the concentration and/or ion activity at the site of calcification, commonly referred to as the "delimited" space (Erez, 2003) or "privileged" space. Elevated

$\left[\mathrm{Ca}^{2+}\right],\left[\mathrm{CO}_{3}{ }^{2-}\right]$ and/or their ion activities have to be actively maintained in order for calcification to proceed. Simultaneously, the concentrations of crystal growth inhibitors have to be lowered even further. Although $\mathrm{CO}_{3}{ }^{2-}$ needed for calcification may be partially derived from respired $\mathrm{CO}_{2}$ (Erez, 1978; Grossman, 1987; Ter Kuile and Erez, 1991; Hemleben and Bijma, 1994; Bijma et al., 1999), the majority of the carbon and the $\mathrm{Ca}^{2+}$ needed for test formation must be derived from the seawater environment.

Calcification requires equal amounts of $\mathrm{Ca}^{2+}$ and $\mathrm{CO}_{3}{ }^{2-}$. Because seawater $\mathrm{Ca}^{2+}$ concentrations are approximately 5 times higher than that of DIC and often $>50$ times higher than that of $\mathrm{CO}_{3}{ }^{2}$, foraminifera have to spend more time and/or energy in taking up and concentrating DIC than they have to do for $\mathrm{Ca}^{2+}$. A foraminifer needs to process several times the seawater equivalent of its own cell volume in order to acquire enough $\mathrm{Ca}^{2+}$ and inorganic carbon to calcify a new chamber. Although the exact amount needed depends on shape, size and the thickness of the chamber wall (e.g. Brummer et al., 1987), juveniles of some species need 50100 times their own cell volume to extract the $\mathrm{Ca}^{2+}$ required to produce one new chamber (De 
150 Nooijer et al., 2009b). Because seawater $\left[\mathrm{CO}_{3}{ }^{2-}\right]$ is significantly lower than $\left[\mathrm{Ca}^{2+}\right]$, these 151 individuals need the equivalent of $\sim 3,000$ times their own volume in order to take up the 152 necessary $\left[\mathrm{CO}_{3}{ }^{2-}\right]$ if this anion is used exclusively. However, observations of high $\mathrm{pH}$ at the 153 site of calcification (Erez, 2003; De Nooijer et al., 2009a; Bentov et al., 2009) as well as 154 oxygen isotope data from laboratory experiments (Spero et al., 1997; Zeebe, 1999) suggest 155 that foraminifera can convert $\mathrm{CO}_{2}$ and/or $\mathrm{HCO}_{3}{ }^{-}$into the $\mathrm{CO}_{3}{ }^{2-}$ needed for calcification. 156 Evidence that foraminifera concentrate inorganic carbon is also provided by experiments 157 using ${ }^{14} \mathrm{C}$ tracer incorporation kinetics into the skeleton of perforate species (Ter Kuile and 158 Erez 1987, 1988, Ter Kuile et al 1989b). A carbon concentrating mechanism would reduce the 159 volume of seawater necessary for calcification by $50-90 \%$ (De Nooijer et al., 2009b). To 160 concentrate the ions needed for calcification, foraminifera must either extract $\mathrm{Ca}^{2+}$ and 161 dissolved inorganic carbon $\left(\mathrm{CO}_{2}, \mathrm{HCO}_{3}{ }^{-}\right.$and $\mathrm{CO}_{3}{ }^{2-}$, or $\left.\mathrm{DIC}\right)$ or take up seawater and 162 subsequently reduce the concentrations and/or activities of all other ions relative to $\mathrm{Ca}^{2+}$ and 163 DIC (Figure 2). Removal of protons from (endocytosed) seawater is also a prominent feature 164 in recently developed calcification mechanisms, but will be discussed in a separate section 165 (2.2). In case of the second option, spontaneous nucleation of $\mathrm{CaCO}_{3}$ crystals may be 166 prevented by separation of $\mathrm{Ca}^{2+}$ and DIC into different vacuole groups.

Figure 2: Two different mechanisms to concentrate $\mathrm{Ca}^{2+}$ and DIC from seawater for calcification: a) Calcium- and bicarbonate-ions are specifically taken up from seawater, or b) the other ions are selectively removed, thereby increasing Ca and DIC concentrations.

172 Both processes transport ions either directly to the site of calcification or temporarily store 173 these ions. In the case of uptake into some benthic foraminifers, $\mathrm{Ca}^{2+}$ and/ or DIC are thought 174 to be present in so-called 'intracellular reservoirs' (also known as 'pools'; Ter Kuile and Erez, 
1988; Erez, 2003). These reservoirs may be seen as temporal storage compartments with high concentrations of ions that are either emptied upon calcification or provide a dynamic cycling of $\mathrm{Ca}^{2+}$ and DIC through the cell that is gradually used for calcification. Without an intracellular reservoir, $\mathrm{Ca}^{2+}$ and DIC could also be directly transported to the privileged space during calcification (Erez, 2003; Bentov and Erez, 2006). The relative importance of intracellular reservoirs versus direct transport among benthic and planktonic species remains a subject of debate and active research.

\subsection{Internal reservoirs}

Internal reservoirs may be important for foraminiferal calcification in certain groups. Conceptually speaking, one can envision $\mathrm{Ca}^{2+}$ or DIC being derived from internal reservoirs. With seawater as the basis for calcification, carbon reservoirs will have to be approximately 5 times larger than those for $\mathrm{Ca}^{2+}$ or have a 5 times faster turnover rate. Evidence suggests that different foraminifer groups employ different strategies. For instance, a time-lag has been observed between uptake and incorporation of labelled inorganic carbon in the large benthic foraminifera Amphistegina lobifera suggesting inorganic carbon may be stored in an internal reservoir (Ter Kuile and Erez, 1987; 1988; Ter Kuile and Erez, 1991). In pulse-chase experiments it was observed that ${ }^{14} \mathrm{C}$ was incorporated into the calcite during the chase period in ${ }^{14} \mathrm{C}$ free seawater, implying a large internal reservoir of DIC in the benthic Amphistegina lobifera but not in the milliolid Amphisorus hemprichii (Ter Kuile et al 1989b). Isotope labelling experiments with the planktonic foraminifer $G$. sacculifer and a number of benthic species using both ${ }^{14} \mathrm{C}$ and ${ }^{45} \mathrm{Ca}$ show that proportionally more labelled ${ }^{45} \mathrm{Ca}$ is incorporated into the shell compared to labelled ${ }^{14} \mathrm{C}$ (Erez, 1978; 1983). For the planktonic species Orbulina universa and Globigerina bulloides, on the other hand, Bijma et al. (1999) showed that the contribution from an internal carbon pool is insignificant in these species. 
To determine whether planktonic foraminifera have an internal Ca-reservoir, Anderson and

201 Faber (1984) grew G. sacculifer in artificial seawater spiked with ${ }^{45} \mathrm{Ca}$. They showed that

202 calcite formed during the first 24 hours contains significantly less ${ }^{45} \mathrm{Ca}$ than that produced in

203 the second 24 hours. These data argue for the existence of an unlabeled intracellular Ca-

204 reservoir that was filled prior to the introduction of the isotopic spike. Using pulse-chase

205 experiments with both a 'hot' incubation period (10-15 days) and 'cold' chase period (10-20

206 days), Erez (2003) traced the uptake of ${ }^{45} \mathrm{Ca}$ over time in the benthic species Amphistegina

207 lobifera, showing that as much as $75 \%$ of the $\mathrm{Ca}^{2+}$ used during chamber calcification resided

208 in an intracellular reservoir. ${ }^{48} \mathrm{Ca}$ uptake data from experiments using Orbulina universa,

209 supported the existence of a Ca-reservoir in a planktonic species, but demonstrated that it was

210 completely flushed of labelled $\mathrm{Ca}^{2+}$ within the initial 6 hours of chamber formation and

211 thickening (Lea et al., 1995). These latter observations could indicate that $O$. universa utilizes

212 a small $\mathrm{Ca}^{2+}$ reservoir to assist with the initial chamber formation, but that much of the

213 remaining chamber $\mathrm{Ca}^{2+}$ is derived from seawater without passing through an internal storage

214 reservoir.

215 Toyofuku et al. (2008) reported formation of (incomplete) chambers in the benthic Ammonia

216 beccarii maintained in seawater devoid of $\mathrm{Ca}^{2+}$. These data clearly support the existence of a

$217 \mathrm{Ca}^{2+}$-reservoir of finite volume in benthic species. If $\mathrm{Ca}^{2+}$ and other divalent cations that co-

218 precipitate in the $\mathrm{CaCO}_{3}$ shell are derived from the same internal reservoir, one would expect

219 cation concentrations to reflect Rayleigh fractionation if the reservoir is a closed system. Such

220 a system has been used to partly explain minor and trace element distributions in

221 foraminiferal calcite (Elderfield et al., 1996). However, a model using Rayleigh fractionation

222 relies on a number of assumptions about the internal reservoir regarding its size and initial

223 composition as well as refreshment rate and chamber calcification rate. These unknowns

224 highlight the need to better constrain the size and extent of these reservoirs. 
225 To maintain an intracellular reservoir, a foraminifer needs to sustain a high cation flux rate by

226 continuously vacuolizing, endocytosing and exocytosing large volumes of seawater. Tracing

227 endo- and exocytosis in foraminifera is challenging and has yielded contrasting results. For

228 instance, Bentov et al. (2009) showed that in Amphistegina lobifera, seawater is taken up in

229 vacuoles that are subsequently transported to the site of calcification. This implies that

230 seawater, internally modified or not, is directly involved in calcification. De Nooijer et al.

231 (2009b) on the other hand, showed that endocytosis and subsequent exocytosis of seawater in

232 Ammonia tepida are not directly related to chamber formation.

233

234

235

236

237

\subsection{Direct uptake of ions}

The ions needed for calcification may be derived from seawater during calcification without storage in an intracellular reservoir (Figure 3). A number of calcification models explicitly or implicitly assume that the ions for calcification are passively transported to the site of calcification through diffusion from the surrounding medium (Wolf-Gladrow et al., 1999; Zeebe et al., 1999). These models are able to explain the impact of photosynthetic symbionts on inorganic carbon chemistry in the vicinity of the foraminifer. Changes in $\mathrm{pH}$ and [DIC] due to photosynthesis affect the isotopic composition of the available carbonate (WolfGladrow et al., 1999). However, diffusion of ions to the site of calcification without at least one additional mitigating mechanism, cannot account for the difference between seawater metal composition and $\mathrm{Me} / \mathrm{Ca}$ ratios in foraminiferal calcite (Figure 1 and references in its caption).

Figure 3: Examples of possible involvement of internal reservoirs versus externally derived ions for calcification. $\mathrm{A}$ : $\mathrm{Ca}^{2+}$ and DIC are derived from internal reservoirs. $\mathrm{B}: \mathrm{Ca}^{2+}$ and DIC are transported to the site of calcification without uptake and storage into reservoirs. C: DIC 
250

251

252

253

254

255

256

257

258

259

260

261

262

263

264

265

266

267

268

269

270

271

272

273

274

is taken up directly and $\mathrm{Ca}^{2+}$ comes from an internal reservoir. $\mathrm{D}: \mathrm{Ca}^{2+}$ is taken up during chamber formation and DIC is derived from an intracellular reservoir.

$\mathrm{Ca}^{2+}$ and DIC may be actively transported (through transmembrane pumps and/ or channels) to the site of calcification. Although such transport mechanisms are not yet identified in planktonic foraminifera, a number of studies support the existence of this mechanism in benthic species. Using radioactive labeling, Angell (1979) showed that the ions for calcification are taken up during chamber formation in the benthic species Rosalina floridana. Although this observation does not prove the absence of an internal reservoir per se, this observation reduces the turnover rate and/or size of such a reservoir considerably. Similarly, Lea et al. (1995) showed that the intracellular Ca-reservoir in the planktonic foraminifer $O$. universa is very small and/or has a fast turnover rate and does not significantly contribute to the total amount of $\mathrm{Ca}^{2+}$ during shell thickening. Results from the benthic Ammonia sp. show that intracellular vesicles containing elevated concentrations of $\mathrm{Ca}^{2+}$ are involved in chamber formation (Toyofuku et al., 2008), but that their amount within the cell is not sufficient for the production of a new chamber (De Nooijer et al., 2009b). Together, these studies suggest that the majority of the $\mathrm{Ca}^{2+}$ utilized for shell calcification is not stored in intracellular reservoirs prior to chamber formation in the species studied. If the internal reservoir refills after chamber formation within a relatively short period of time, it is critical that seawater labeling experiments should start directly after a chamber formation event to avoid underestimation of the true reservoir size. Studies addressing the issue of an intracellular reservoir are summarized in Table 1.

Table 1: Studies discussing internal reservoirs in perforate foraminifera. 


\section{Intracellular transport}

\subsection{Transmembrane ion transport}

Due to the hydrophobic inner layer of cell membranes, molecules cannot freely move into or out of the cell's interior. Although the majority of ions and molecules diffuse across cell membranes, diffusion constants vary greatly. Small, uncharged molecules $\left(\mathrm{CO}_{2}, \mathrm{O}_{2}, \mathrm{NO}\right)$ diffuse easily down a concentration gradient whereas large molecules and ions require specialized transmembrane proteins to facilitate or energize membrane transport (Higgins, 1992). These transporter proteins can be divided into channels, carriers and pumps (Figure 4). Carrier proteins undergo substrate binding and transport. They show typical substrate affinities and follow Michaelis-Menten kinetics. Carrier transport is even effective against concentration gradients if a cosubstrate with a respective concentration gradient or charge is involved (secondary active transport). Pumps directly generate this energy for uphill transport from their ATPase activity. Transmembrane channels simply allow facilitated diffusion along electrochemical gradients by creating a selective pore through the cell membrane. For the uptake of inorganic carbon by foraminifera during calcification, a strong $\mathrm{pH}$ gradient (high inside; De Nooijer et al., 2009a; Bentov et al., 2009; low outside; Glas et al., 2012) may promote the influx of $\mathrm{CO}_{2}$ and thus circumvent the need for specialized transmembrane proteins.

Figure 4: selective ion transporters. Ion pumps (left and middle) undergo structural changes that allow passage of ions from and to the binding sites. The example shown here is a simplified $\mathrm{Na}^{+} / \mathrm{K}^{+}$exchanger that has specifically binds to Na-ions (blue squares) when in the first configurational state (left). After the structural change, affinity of the Na-binding sites decreases so that the Na-ions are released (middle). At the same time, K-ions (yellow circles) 
bind to their binding sites after which the pump returns to state one and releases the $K^{+}$to the cytosol. Ion channels (draw after the KcsA $K^{+}$channel; right) consist usually of a narrow pore allowing certain ions to pass a cell membrane down the electro-chemical gradient. Another feature of some pumps and channels is the relatively large cavity that is created by the transmembrane protein-complex (here present in the cytosol-side of the channel). This can greatly reduce the distance that the ions have to be transported. The type of $\mathrm{Ca}^{2+}$-transporters that are used by foraminifera are unknown, but determining their molecular structure is necessary to 1) know the extent of de-hydration during transport, 2) determine the rate of ion transport and 3) explain the selectivity for $\mathrm{Ca}^{2+} /$ against other ions (e.g. $\mathrm{Mg}^{2+}$ ) and their fractionation (e.g. Gussone et al., 2003).

\section{$3.2 \mathrm{Ca}^{2+}$ transport in foraminifera}

In foraminifera, most attention has been directed at ion transporters that might be responsible for the low $\mathrm{Mg} / \mathrm{Ca}$ at the site of calcification. Logically, this may involve $\mathrm{Mg}^{2+}$-transporters and/ or $\mathrm{Ca}^{2+}$ transporters. Because $\mathrm{Ca}^{2+}$ acts as a secondary messenger in most eukaryotic cells, cytosolic $\mathrm{Ca}^{2+}$ is kept low $(<1 \mu \mathrm{M})$ by active removal out of the cell or into cytosolic compartments (ER, mitochondria). This makes $\mathrm{Ca}^{2+}$-transporters one of the most ubiquitous and well-studied transmembrane ion transporters. From a variety of cell types, $\mathrm{Ca}^{2+}$-ATPases, $\mathrm{Ca}^{2+} / \mathrm{H}^{+}$and $\mathrm{Ca}^{2+} / \mathrm{Na}^{+}$antiporters (e.g. Gonçalves et al. 1998) and $\mathrm{Ca}^{2+} /$ phosphate cotransporters (Ambudkar et al., 1984) have been described. Depending on the transporter's structure, ions may pass the membrane either with or without their hydration sphere (Gouaux and MacKinnon, 2005), although (partial) dehydration increases the selectivity greatly (see also Gussone et al., 2003).

The specificity of the transmembrane Ca-transporters varies greatly. For some $\mathrm{Ca}^{2+} / \mathrm{H}^{+}$antiporters it has been reported that other cations with a small ionic radius (e.g. $\mathrm{Zn}^{2+}$ ) can be 
transported in a similar way as $\mathrm{Ca}^{2+}$ is transported (Gonçalves et al., 1999). For the same antiporter, the larger $\mathrm{Ba}^{2+}$ and $\mathrm{Cs}^{+}$do not substitute for $\mathrm{Ca}^{2+}$. An ion with intermediate size, $\mathrm{Sr}^{2+}\left(1.13 \AA\right.$, compared to $0.99 \AA$ for $\left.\mathrm{Ca}^{2+}\right)$, appears to block the antiport and prevents transport of $\mathrm{Ca}^{2+}$ through the membrane. Studies concerning specificity for $\mathrm{Ca}^{2+}$ over $\mathrm{Mg}^{2+}$ are scarce, but some Ca-ATPases have been reported to have a $10^{3}-10^{5}$ higher affinity for $\mathrm{Ca}^{2+}$ than for $\mathrm{Mg}^{2+}$ (Drake et al., 1996; Xiang et al., 2007).

In corals, calcium uptake is directly related to proton pumping (McConnaughey and Whelan, 1997; Sinclair and Risk, 2006). The efflux of $\mathrm{H}^{+}$during calcification (Glas et al., 2012) may therefore help to constrain estimates of calcium pumping rates during calcification. Carbon dioxide uptake and proton efflux are also directly related in cyanobacteria (Ogawa and Kaplan, 1987). Ter Kuile et al. (1989b) suggested that $\mathrm{Ca}^{2+}$ is taken up by $\mathrm{Ca}^{2+}$-ATPase and this mechanism was subsequently used by Zeebe and Sanyal (2002) and Zeebe et al. (2008) to show that $\mathrm{H}^{+}$removal is far more energy-efficient than $\mathrm{Mg}^{2+}$-removal during calcification. Such a mechanism would be consistent with a coupling of ion transporters (e.g. $\mathrm{Ca}^{2+}$ and $\mathrm{H}^{+}$) during foraminifera calcification.

The amount of $\mathrm{Ca}^{2+}$ transported across a membrane depends on 1) transporter density in the membrane, 2) affinity for $\mathrm{Ca}^{2+}$ of the transporter and 3) the capacity of the transporter. For example, the $\mathrm{Na}^{+} / \mathrm{Ca}^{2+}$ exchanger has a low affinity, but high capacity, resulting in transport of up to 5,000 ions per second (Carafoli et al., 2001). Such a transporter is useful when $\mathrm{Ca}^{2+}$ is present in high concentrations (e.g. as in seawater) and supply or removal rates of $\mathrm{Ca}^{2+}$ have to be high. Cell membrane calcium pumps, on the other hand have a high affinity, but low capacity, making it particularly suitable for transporting $\mathrm{Ca}^{2+}$ out of a medium or compartment with a low $\left[\mathrm{Ca}^{2+}\right]$ (Wang et al., 1992). Finally, transport rates can be affected by the presence of inhibitors, high intracellular $\left[\mathrm{Ca}^{2+}\right]$ (e.g. Pereira et al., 1993) or shortage of ATP (in case of e.g. $\mathrm{Ca}^{2+}$-ATPase). 


\subsection{Inorganic carbon transport in foraminifera}

352 Transport of inorganic carbon may be accomplished by bicarbonate-transporters. If seawater or metabolic $\mathrm{CO}_{2}$ contributes to the inorganic carbon during calcification, diffusion rates across membranes would control the influx of inorganic carbon and thereby influence the rate of calcification. The diffusion rate is determined by the concentration gradient of $\mathrm{CO}_{2}$, the membrane area over which $\mathrm{CO}_{2}$ can diffuse, and the solubility of $\mathrm{CO}_{2}$ in the membrane lipids.

357 The concentration of $\mathrm{CO}_{2}$ at the site of calcification or in internal reservoirs is determined by pH. Since foraminifera can control the $\mathrm{pH}$ in these compartments (Erez, 2003; Bentov et al., 2009; De Nooijer et al., 2009a; Glas et al., 2012), they can produce large $\mathrm{CO}_{2}$ concentration gradients and hence promote the influx of DIC to the sites of calcification. The flux of ions can also be calculated from calcification rates, which is discussed in section 4 .

In case of intracellular storage of ions, calcium and DIC are unlikely to be stored as free ions. Because the cytosol has very low concentrations of free $\mathrm{Ca}^{2+}$ and DIC, the cell volume will control the number of ions available for calcification. For the DIC-reservoir (if present) the additional problem is that $\mathrm{CO}_{2}$ can easily diffuse across cell membranes and subsequent reequilibration would thus result in net leakage of carbon out of the DIC-reservoir. To overcome this problem, DIC must be sequestered by mechanisms such as elevating the $\mathrm{pH}$ in the reservoir. Because there are usually no crystallites visible within the cells of hyaline species, $\mathrm{Ca}$ and DIC are likely sequestered together as non-crystalline $\mathrm{CaCO}_{3}$ (i.e. amorphous calcium carbonate or ACC). Such a possibility may have consequences for the minor and trace element composition of the calcite precipitated, since it is known that formation of high2000). 
374 Regardless of the process concentrating $\mathrm{Ca}^{2+}$ and DIC from seawater, each would produce a 375 supersaturated solution at the site of calcification, with reduced levels of crystal inhibitors that 376 occur naturally in seawater (e.g. $\mathrm{Mg}^{2+}$ and $\mathrm{PO}_{4}{ }^{2-}$ ). The $\mathrm{Ca}^{2+}$ and $\mathrm{CO}_{3}{ }^{2-}$ may form spontaneous $377 \mathrm{CaCO}_{3}$ crystals, but the specific morphology of foraminiferal chambers show that nucleation 378 and crystal growth is a tightly controlled process.

379

\section{Nucleation of calcification}

\subsection{Crystal nucleation energy and critical size}

Precipitation of a crystal from a solution occurs when free energy of the precipitate is lower than that of the solution. Nucleation of a crystal requires even more energy since ions at the surface of a crystal add to the free energy of the solid phase. This is caused by the fact that ions at the surface of a crystal are not bound on all sides to other ions. The resulting 'interfacial energy' requires the formation of metastable clusters of a critical size to start crystal growth (Figure 5). The interfacial free energy between the cluster and a solution is usually larger than that between the cluster and a solid substrate, resulting in crystal nucleation at solid surfaces rather than within the solution itself (De Yoreo and Vekilov, 2003). If the atomic structure of a substrate matches a particular plane of the nucleating phase (e.g. calcite or aragonite), the interfacial free energy is reduced and nucleation is promoted (De Yoreo and Vekilov, 2003).

In the case of nucleation of $\mathrm{CaCO}_{3}$, presence of negatively charged groups at regular intervals at the site of calcification may be able to bind $\mathrm{Ca}^{2+}$ and pre-form a part of the $\mathrm{CaCO}_{3}$ lattice.

Figure 5: relation between free energy changes ( $\Delta g)$ as a function of pre-nucleation sphere (r), where $\Delta g_{s}$ is the surface term and $\Delta g_{b}$ the bulk term. The sum of $\Delta g_{s}$ and $\Delta g_{b}$ is the free 
energy barrier that can only be overcome by the formation of a nucleation sphere with a critical size $\left(r_{c}\right)$. Biological control over crystal nucleation is often aimed at lowering of this energy barrier and can be achieved by increasing the concentrations of the solutes or the presence of an organic template.

\subsection{Organic templates and nucleation of $\mathrm{CaCO}_{3}$ in foraminifera}

During biomineralization in foraminifera calcium carbonate nucleates at the site of calcification, likely involving an organic template. In all Rotaliid foraminifera, chamber formation starts with delineation of a finite environment that encompasses an inner chamber volume from the surrounding medium (Angell, 1979; Bé et al., 1979; Hemleben et al., 1986;

Spero, 1988; Wetmore, 1999). Cytoplasmic activity by formation of a dense pseudopodial network transports vacuoles, mitochondria and organic particles to a defined zone in which the so-called Organic Primary Envelope, Primary Organic Lining, Anlage or Primary Organic Membrane (POM) is formed (e.g. Banner et al., 1973; Hemleben et al., 1977; Spero, 1988; not to be confused with inner and outer organic linings, nor with the outer protective envelope or cytoplasmic envelope: see section 4). The term POM is often used but may be confusing (Erez, 2003) since these organic templates are not technically membranes. Therefore, we recommend following the suggestion of Erez (2003) to rename the POM as the Primary Organic Sheet (POS). In a number of benthic species, the POS consists of unbranched polysaccharides such as glycosaminoglycans (Hottinger and Dreher, 1974; Langer, 1992). Proteins are also present in the organic lining of foraminifera, sometimes forming different classes based on their amino acid composition (Robbins and Brew, 1990). King and Hare (1972) showed that amino acids make up $0.02-0.04 \%$ of the weight of the calcite and that composition among planktonic species varies greatly. Interestingly, the largest compositional difference coincides with the planktonic foraminifera spinose/ non-spinose divide (King and 
Hare, 1972), but differences in amino acid composition are also manifest at lower taxonomic

425 levels (Robbins and Healy-Williams, 1991).

426 The organic matrix of the benthic Heterostegina depressa is shown to contain an EDTA427 soluble and -insoluble fraction (Weiner and Erez, 1984). The insoluble fraction contains oversulphated glycosaminoglycans and a small portion of non-polar proteins, forming the inner organic lining. The soluble fraction contains a number of proteins containing amino acids with acidic residues. Polar groups in both fractions may be involved in biomineralization since they may bind $\mathrm{Ca}^{2+}$ ions and thereby overcome the free energy barrier (Figure 5). If such groups are regularly spaced, they may help nucleation further by placing the $\mathrm{Ca}^{2+}$ ions in a regular grid with just enough space for the $\mathrm{CO}_{3}{ }^{2-}$ ions to fit in between them. To test this hypothesis, the tertiary structures of the biomolecules (e.g. proteins and saccharides) that are involved in $\mathrm{CaCO}_{3}$ nucleation need to be analyzed.

The presence of polysaccharides and proteins has led to the hypothesis that the POS has two 437 functions in the process of calcification. The carbohydrates may form a structure determining 438 the overall shape of the new chamber. The proteins associated with the polysaccharides, on the other hand, form the 'active' part of the POS by providing charged sites for nucleation of $\mathrm{CaCO}_{3}$ (Towe and Cifelli, 1967). Since the chemical composition of the POS varies between species (Banner et al., 1973), its role in nucleation of calcium carbonate may differ between

442 foraminiferal species (Bé et al., 1979; Hemleben et al., 1986; Spero, 1988; Wetmore, 1999). 443 In some benthic species, the POS coincides with the location of the pores prior to calcification 444 (Wetmore, 1999), suggesting that there are structural differences in the POS within a single chamber that determine where calcite does and does not nucleate. In planktonic species such as Globorotalia truncatulinoides and G. hirsuta, calcification begins in small nucleation zones 447 at finite locations across the POS, where calcite forms centers of crystal growth that interlock 448 to form the initial calcified chamber (Towe and Cifelli, 1967; Angell, 1979; Bé et al., 1979; 
Hemleben et al., 1986). A similar pattern has been observed in Orbulina universa, where 450 small islands of calcite form on the POS, followed by calcite island fusion to produce the 451 spherical chamber (Spero, 1988).

452 Nucleation (and subsequent crystal growth) is also determined by the physico-chemical 453 conditions at the site of calcification. These conditions are only partly known in benthic 454 species (e.g. Erez, 2003; Bentov and Erez, 2005) and have only been modeled in planktonic 455 species (Zeebe et al., 1999; Zeebe and Sanyal, 2002). The volume between the crystal surface 456 and the shielding cytoplasmic envelope or pseudopodial network is extremely small, limiting interpretation from light microscopic observations. However, TEM images of initial calcification in Orbulina universa and other planktonic species suggests the privileged space between rhizopodia and calcifying surfaces may be <10 nm (Bé et al 1979; Spero 1988). Little is known about the chemical composition of the fluid from which $\mathrm{CaCO}_{3}$ nucleates, but high concentrations of $\mathrm{Ca}^{2+}$ and $\mathrm{CO}_{3}{ }^{2-}$ need to be actively maintained, while the $\left[\mathrm{Mg}^{2+}\right]$ needs 462 to be reduced to satisfy observations and ensure calcification (Zeebe and Sanyal, 2002). 463 Elevated $\mathrm{pH}$ at the site of calcification would promote the conversion of $\mathrm{CO}_{2}$ and $\mathrm{HCO}_{3}{ }^{-}$to $464 \mathrm{CO}_{3}{ }^{2-}$, thereby enhancing $\mathrm{CaCO}_{3}$ nucleation and growth. Elevated concentrations of $\mathrm{Mg}^{2+}$ 465 around the POS in Pulleniatina obliquiloculata (Kunioka et al., 2006) may indicate that in this species, the composition of the calcifying fluid is different during the first stage of chamber formation, possibly due to a different rate or efficiency of the process that locally reduces $\left[\mathrm{Mg}^{2+}\right]$ vs $\left[\mathrm{Ca}^{2+}\right]$. The participation of a small volume of seawater at the beginning of 469 chamber formation may explain the elevated $\mathrm{Mg}$ in the first calcite precipitated, although this pattern does not hold for other planktonic species (e.g. such as Orbulina universa; Eggins et al., 2004) where the lowest $\mathrm{Mg} / \mathrm{Ca}$ ratios are associated with the intrashell zone that corresponds to the POS. The above observations of inter species differences in chamber wall 
473 elemental composition underscore the need to unravel the mechanisms controlling test 474 calcification.

475

\section{Chamber growth}

After initial crystal nucleation, calcification proceeds by addition of calcite on both sides of the POS. Additional layers of $\mathrm{CaCO}_{3}$ are added on top of pre-existing chamber calcite during each chamber formation event in perforate foraminifera (Reiss, 1957; 1960; Bé and Hemleben, 1970; Erez, 2003). Together, the primary and secondary layers of calcite are termed 'lamellar' calcite (Erez, 2003). Most observations on calcification are based on the first stage of chamber formation in which a thin-walled chamber is produced within 1-3 hours (Spero, 1988). Subsequent thickening of the chamber wall proceeds during the next 24-48 hours until a new chamber is formed. Thickening of earlier formed chambers occurs by addition of a calcite layer with each new chamber formation event (e.g. Bentov and Erez 2005, Nehrke et al., 2013). Future studies will need to show whether the timing of the start and end of chamber formation and thickening of previously formed chambers are coincidental, or whether thickening is a continuous process.

Future biomineralization research should also take into account the possibility that cellular controls on calcification may vary over time and location across the foraminifera shell. An example of the potential complexity and diversity of calcification within one specimen is provided by Bentov and Erez (2005). Their research demonstrated that the benthic Amphistegina lobifera recovering individuals produce at least three types of calcium carbonate: elongated, intracellular birefringent granules with a high magnesium and phosphorus content, extracellular microspheres with a high $\mathrm{Mg}$ concentration and 
calcite while the microspherulites represent the initial presipitation over the POS in $A$.

499 lobifera.

500 During chamber formation, ions could be supplied to the site of calcification (SOC) from

501 internal reservoirs (Figure 3, Table 1) or by transport from the surrounding seawater. The

502 latter can be accomplished by transmembrane ion transporters (section 2), by direct exchange

503 of the calcifying fluid with seawater and/ or by diffusion from ambient seawater. The inner

504 and outer surfaces of newly formed chambers of the benthic Heterostegina depressa are

505 covered by thin layer of cytoplasm (Spindler, 1978), suggesting the SOC may be separated

506 from the surrounding medium. In a number of studies (Angell, 1979; Bé et al., 1979), a fan-

507 like arrangement of the pseudopodial network is observed in a zone outside the site of

508 calcification. Although the relation between this arrangement and calcification remains to be

509 investigated, it is likely to play a role in biomineralization since this dense network is not

510 observed between chamber formation events. Also in the planktonic species G. hirsuta and G.

511 truncatulinoides, calcification proceeds adjacent to a cytoplasmatic envelope (or outer

512 protective envelope) that may play a role in maintaining SOC integrity and shape, and

513 promoting initial calcification (Bé et al., 1979). In the benthic Ammonia sp., a pH gradient of

$514>2 \mathrm{pH}$ units is observed across several $\mu \mathrm{m}$ distance and is maintained for hours between the

515 site of calcification (De Nooijer et al., 2009a) and the specimen's microenvironment (Glas et

516 al., 2012). These observations suggest that in Ammonia sp., the SOC is separated from the

517 outside environment. Spero (1988) on the other hand, presented transmission electron

518 micrographs that showed the site of calcification in O. universa is not shielded by a

519 continuous membrane. Nehrke et al. (2013) recently suggested that the site of calcification in

520 Ammonia aomoriensis is largely closed from the surrounding medium, but that a small

521 percentage of the fluid at the SOC is derived from leakage of the cell membranes separating it

522 from the outside medium, explaining observed $\mathrm{Mg} / \mathrm{Ca}$ for the species studied. 
523 The extent to which the site of calcification is open or closed, in combination with the

524 presence or absence of intracellular ion reservoirs, is an important unknown in understanding

525 foraminiferal calcification (Figure 6). For example, a site of calcification that is physically

526 separated from the surrounding seawater, together with the absence of intracellular ion

527 reservoirs, prescribes the need for transmembrane ion transporters (e.g. $\mathrm{Ca}^{2+}$-APTase; section

528 II) that selectively pump ions from seawater to the SOC. A SOC that is open, on the other

529 hand, will experience relatively high concentrations of $\mathrm{Mg}$ and require an active $\mathrm{Mg}^{2+}$ -

530 removal mechanism.

531

532 Figure 6: summary of the most important parts of the calcification mechanism in

533 foraminifera, including Ca-ion transport, active Mg-removal and contribution from internal

534 reservoirs. See text for description of the individual processes.

536 Potential ion transport pathways to the site of calcification can be constrained from

537 calcification rates during chamber formation. It is important to distinguish between the overall

538 growth rate of a foraminifer and calcite precipitation rate during biomineralization. The

539 difference between these processes results from the episodic nature of growth (chamber

540 addition) in foraminifera. Some planktonic species have been reported to increase the weight

541 of their shell by $13-15 \%$ a day (G. sacculifer; Erez, 1983), but this may vary with

542 environmental conditions (Ter Kuile and Erez, 1984 and references therein). Secondly,

543 chamber addition rates vary over a foraminifer's lifetime, decreasing as the individual ages

544 (Ter Kuile and Erez, 1984). Calcite precipitation rates during chamber addition, on the other

545 hand, are much higher and vary between $0.4-0.9 \mu \mathrm{g} / \mathrm{h}$ in the planktonic foraminifer $G$.

546 sacculifer (Anderson and Faber, 1984), 0.06-0.32 $\mu \mathrm{g} / \mathrm{h}$ in O. universa (Lea et al., 1995) and

$547 \sim 10 \mu \mathrm{g} / \mathrm{h}$ in the benthic A. tepida (De Nooijer et al., 2009b). Since such rates are rarely 
quantified, it is difficult to generalize these values to other species or other conditions. Moreover, calcite precipitation rates can be variable between day and night calcification periods (Erez, 1983; Spero, 1988; Lea et al., 1995). Since incorporation of some elements may depend on precipitation rate (e.g. DePaolo, 2011), it is necessary to quantify these rates across a diurnal time frame when chamber formation is occurring in order to assess the kinetics of element incorporation and thereby proxy-relationships.

Mitochondrial activity may play an important role at the site of calcification and thereby affect trace element incorporation. Besides providing energy, mitochondria pump cytosolic $\mathrm{Ca}^{2+}$ and $\mathrm{Mg}^{2+}$, and therefore modulate the cell's $\left[\mathrm{Ca}^{2+}\right]$ and $\left[\mathrm{Mg}^{2+}\right]$ (Carafoli et al., 2001). This may be particularly important during calcification when the concentration of these ions increases locally. Spero (1988) shows that calcification in O. universa around the POS is associated with pseudopodia containing mitochondria, and hence possibly modulate $\left[\mathrm{Mg}^{2+}\right]$ at the SOC. Similar results can be found in Bé et al (1979) for Globorotalia truncatulinoides. Bentov et al (2009) discuss the possible role of mitochondria in producing metabolic $\mathrm{CO}_{2}$ that eventually accumulate in the alkaline vacuoles as DIC.

Photosynthesis by symbionts may also affect calcification rates. The relative concentrations of DIC species are influenced by symbiont photosynthesis and $\mathrm{CO}_{2}$-uptake during the day (or release in the dark) and the resulting diurnal differences in microenvironment $\mathrm{pH}$ (Jørgensen et al., 1985; Rink et al., 1998; Köhler-Rink and Kühl, 2000; 2005), thereby influencing uptake and availability of inorganic carbon species. In some large benthic foraminifera (Wetmore, 1999), the symbionts are positioned near the POS prior to calcification, suggesting that their activity could enhance calcification. Elimination of symbionts in G. sacculifer resulted in reduced chamber formation rates and early gametogenesis or death of the foraminifera (Bé et al., 1982). Reseeding the aposymbiotic foraminifera with symbionts from donor specimens produced individuals that continued to add chambers and mature at a normal rate. These data 
suggest that symbiont photosynthesis is critical to both nutrition and chamber calcification. Elevated light intensity promotes growth in G. sacculifer (Caron et al., 1982) but not in the benthic foraminifera Amphistegina lobifera in which both photosynthesis and calcification are optimal at relatively low light intensities that are found at 20-30 m water depth (Erez 1978, Ter Kuile and Erez, 1984).

Ter Kuile et al. (1989a), on the other hand, suggested that symbionts and foraminifera compete for inorganic carbon. Erez (1983) and Ter Kuile et al. (1989b) showed that inhibition of photosynthesis in both planktonic and benthic species by the photosystem II inhibitor DCMU, does not affect calcification rates and suggested that it is not photosynthesis itself, but rather light which directly promotes calcification. Finally, Ter Kuile et al (1989a) have shown that there is competition for $\mathrm{CO}_{2}$ between the symbionts and their host in the benthic foraminiferan A. lobifera. Clearly, the relationship between symbioses and foraminifera calcification requires additional study.

Pore formation provides important information on foraminiferal biomineralization. In species producing macropores, we observe a pore plate that is continuous with the POS and separates the cytoplasm from the outside medium (Hemleben et al., 1977). In benthic, symbiont-bearing species, symbionts can be found in close proximity to the pores (e.g. Lee and Anderson, 1991) suggesting that respiratory gases such as $\mathrm{CO}_{2}$ and $\mathrm{O}_{2}$ may be able to diffuse through the pore plates. In symbiont-barren species, diffusion of gases between cytoplasm and environment could be enhanced by the permeability of a pore plate. Some have suggested that dissolved organic matter may be taken up through the pores in the benthic Patellina (Berthold, 1976). In G. sacculifer, pseudopodia appear to penetrate through the pore plates (Anderson and Bé, 1976). Pores in the benthic species Patellina corrugata have been reported to exist from the beginning of chamber formation (Berthold, 1976) and pores are observed in the O. universa sphere once initial calcification has locked in the spherical morphology of the chamber 
598 (Spero, 1988). Some species of planktonic foraminifera have micro- instead of macropores

599 (often in species with secondary apertures; Globigerinata glutinata, Candeina nitida), ranging 600 from 0.3-0.7 $\mu \mathrm{m}$ (Brummer and Kroon, 1988). These micropores do not appear to have a pore 601 plate, and their function, formation and morphology is less well understood than those for 602 macropores.

603 as 'ontogenetic' or 'lamellar' calcite (Erez, 2003). Additional $\mathrm{CaCO}_{3}$ can be present as ornamentations (pustules, spines, ridges, tooth plates, etc.) or as layers of calcite covering the whole test (crust or gametogenic (GAM) calcite). Whereas ornamentation is present throughout the entire life cycle of a foraminifer (Hemleben, 1975), GAM calcite is exclusive to planktonic foraminifera and is added after the last chamber is formed and just prior to meiotic division of the nucleus and gametogenesis.

612 In some planktonic species, a calcite crust can be formed after formation of the final chamber 613 (Bé and Ericson, 1963; Bé and Lott, 1964; Bé, 1965; Bé and Hemleben, 1970; Olsson, 1976). 614 The morphology of this calcite is markedly different from that of either ontogenetic or GAM 615 calcite and its element and isotopic composition can differ from that of the ontogenetic calcite 616 because it forms under different environmental conditions of temperature and/or salinity. For 617 instance, crust $\mathrm{Mg} / \mathrm{Ca}$ is generally lower than that of ontogenetic calcite in Globorotalia 618 truncatulinoides (Duckworth, 1977) and Neogloboquadrina dutertrei (Jonkers et al., 2012). These lower element concentrations are partly a consequence of conditions deeper in the water column (i.e. lower temperature), but it should be noticed that the observed partitioning

621 for $\mathrm{Mg}$ indicates that crust calcification is a biologically controlled process. Interestingly, 
622 Nürnberg et al. (1996) found that crusts formed in culture can have a higher $\mathrm{Mg} / \mathrm{Ca}$ than the 623 ontogenetic calcite.

624 In a number of species such as G. sacculifer, gametogenesis is preceded by the production of 625 a layer of calcite covering spine holes and the terrace-like structures of inter-pore rims (Towe 626 and Cifelli, 1967; Bé, 1980; Hemleben et al., 1985; Brummer et al., 1987). This GAM calcite

627 veneer gives the foraminifera a smooth appearance by covering the rough topography of the 628 shell surface and it has been suggested that it is enriched in some trace elements compared to 629 the ontogenetic calcite (Hathorne et al., 2009). Whether this observation holds for all 630 foraminifera forming GAM calcite, however, remains to be investigated.

631 From the perspective of biomineralization, variability in the types of $\mathrm{CaCO}_{3}$ that are formed 632 may indicate that foraminifera do not have one single way to produce shell calcite. Rather, the 633 physiological tools to achieve calcite precipitation as discussed in sections 2 and 4, are likely 634 used in different combinations by different species of foraminifera. Moreover, the variability 635 in calcite within single specimens suggests a degree of flexibility of these physiological tools 636 even within single species. Identification of seawater vacuolization, transmembrane ion 637 transport, nucleation promoting organic templates, etc. across species and their contribution to 638 calcification within a foraminifer's life time are critical aspects of foraminiferal biology and 639 keys to understanding foraminiferal biomineralization from a mechanistic perspective.

\section{Future directions}

642 A complete mechanistic description of foraminiferal biomineralization and chamber formation does not yet exist. Hence, the biological and environmental interplay that controls

644 the element composition and isotope fractionation of chamber calcite is only partly 645 understood. Literature on foraminiferal calcification is both qualitative and quantitative but on 
646 occasion, contradictory. This leaves us with a number of outstanding questions that need to be

647 addressed in order to move this area of foraminifera biology forward. These include:

648

649 1. Which foraminiferal species use vacuolized seawater as the primary source for calcification and which use transmembrane transport of $\mathrm{Ca}^{2+}$ and DIC during calcification? The investigation into the transport of ions to the site of calcification may be solved by answering a number of more practical questions, including:

- What is the relation between transmembrane transport and vaculization on the one hand, and production of intracellular calcium and/ or carbon reservoirs on the other hand?

- What is the biochemical basis of these processes? Which transmembrane transporters are involved (e.g. Ca-ATPases, proton- $\mathrm{Ca}^{2+}$ antiporters)? By which mechanism is inorganic carbon concentrated (e.g. involvement of Carbonic Anhydrase)?

- When characterized, can these (transport) mechanisms explain observed element incorporation and isotopes fractionations. If yes, can these mechanisms explain foraminiferal chemistry for (all) these elements and isotopes at the same time?

- Is there a general difference between planktonic and benthic species in production of vacuolized seawater, internal reservoirs and/or direct ion transport?

- Do foraminifera employ both mechanisms to calcify and if yes, what is the balance between these two pathways?

2. What is the tertiary structure of the organic matrix/ matrices (e.g. POS, organic linings) involved in biomineralization? Which compounds help to lower the free energy barrier, thereby promoting calcite nucleation? When identified, do these organic compounds have an impact on the partition coefficient of elements and fractionation of isotopes at the first stage of chamber formation? 
676

677 Finally, a more detailed understanding of foraminiferal biominiralization will also allow 678 researchers to compare calcification strategies accross marine calcifiers. Compared to 679 foraminifera, biomineralization in corals (Al-Horani et al., 2003; Sinclair and Risk, 2006; 680

681

682

687

688

689

3. To what extent is the site of calcification in contact with surrounding seawater? If seawater directly contributes (part of) the ions for calcification, can this source explain observed fractionation factors and partition coefficients?

4. What is the role of mitochondria in calcification? Do mitochondria (help to) regulate the $\mathrm{Mg} / \mathrm{Ca}$ at the site of calcification?

Venn et al., 2013), coccolithophores (Marsh, 2003; Taylor et al., 2011; Ziveri et al., 2012;

Bach et al., 2013), gastropods (e.g. Nehrke et al., 2011) and bivalves (Nudelman et al., 2006;

Nehrke et al., 2012; Shi et al., 2013) are understood in greater detail. Identification of differences and similarities between these marine calcifying taxa will allow studying (convergent) evolutionairy patterns, help to understand differences in their response to (future) environmental perturbations and facilitate comparison of paleoceanographic information obtained across taxa.

\section{Acknowledgements}

Darwin Center, Discussions with Gernot Nehrke (AWI) and Gerald Langer (AWI, Cambridge) greatly helped develop the ideas that are presented in this paper. This paper was the result of research supported by the European Commission through grant 211384 (EU FP7 "EPOCA"), grant 265103 (EU FP7 "MedSeA"), by support through the German Federal Ministry of Education and Research (BIOACID; BMBF, FKZ 03 F0608) and by support of the Darwin Center for Biogeosciences. Howard Spero acknowledges the support of the 
695 Alexander von Humboldt Foundation. Jonathan Erez acknowledges the support of the Israel 696 Science Foundation grant 551/10.

697

698

\section{References}

699

700

701

702

703

704

705

706

707

708

709

710

711

712

713

714

715

716

717

718

Al-Horani, F.A., Al-Moghrabi, S.M., De Beer, D., 2003. Microsensor study of photosynthesis and calcification in the scleractinian coral, Galaxea fascicularis: active internal carbon cycle. J. Exp. Mar. Biol. Ecol. 288, 1-15.

Allen, K.A., Hönisch, B., Eggins, S.M., Yu, J., Spero, H.J., Elderfield, H., 2011. Controls on boron incorporation in cultured tests of the planktic foraminifer Orbulina universa. Earth Planet. Sci. Lett. 309, 291-301.

Ambudkar, S.V., Zlotnick, G.W., Rosen, B.P., 1984. Calcium efflux from Escherichia coli. Evidence for two systems. Journal of Biol. Chem. 259, 6142-6146.

Anderson, O.R., Bé, A.W.H., 1976. The ultrastructure of a planktonic foraminifer, Globigerinoides sacculifer (Brady), and its symbiotic dinoflagellates. J. Foramin. Res. $6,1-21$

Anderson, O.R., Faber, W.W. Jr, 1984. An estimation of calcium carbonate deposition rate in a planktic foraminifer Globigerinoides sacculifer using ${ }^{45} \mathrm{Ca}$ as a tracer: a recommended procedure for improved accuracy. J. Foramin. Res. 14, 303-308.

Angell, R.W., 1979. Calcification during chamber development in Rosalina floridana. J. Foramin. Res. 9, 341-353.

Bach, L.T., Mackinder, L.C.M., Schultz, K.G., Wheeler, G., Schroeder, D.C., Brownlee, C., Riebesell, U., 2013. Dissecting the impact of $\mathrm{CO}_{2}$ and $\mathrm{pH}$ on the mechanisms of photosynthesis and calcification in the coccolithophore Emiliania huxleyi. New Phytol. $199,121-134$ 
Banner, F.T., Sheehan, R., Williams, E., 1973. The organic skeletons of rotaline foraminifera: A review. J. Foramin. Res. 3, 30-42.

Bé, A.W.H., Ericson, D.B., 1963. Aspects of calcification in planktonic foraminifera (Sarcodina). New York Acad. Sci., Ann., vol. 109, art. 1, pp. 65-81.

Bé, A.W.H., Lott, L., 1964. Shell growth and structure of planktonic foraminifera. Science $145,823-824$.

Bé, A.W.H., 1965. The influence of depth on shell growth in Globigerinoides sacculifer (Brady). Micropaleontology 11, 81-97.

Bé, A.W.H., 1980. Gametogenic calcification in a spinose planktonic foraminifer, Globigerinoides sacculifer (Brady). Mar. Micropaleontol. 5, 283-310.

Bé, A.W.H., Hemleben, C., 1970. Calcification in a living planktonic foraminifer, Globigerinoides sacculifer (Brady). N. Jb. Geol. Paläont. Abh. 134, 221-234.

Bé, A.W.H., Hemleben, C., Anderson, O.R., Spindler, M., Hacunda, J., Tunitivate-Choy, S., 1977. Laboratory and field observation of living planktonic foraminifera. Micropaleontology 23, 155-179.

Bé, A.W.H., Hemleben, C., Anderson, O.R., Spindler, M., 1979. Chamber formation in planktic foraminifera. Micropaleontology 25, 294-307.

Bé, A.W.H., Spero, H.J., Anderson, O.R., 1982. Effects of symbiont elimination and reinfection on the life processes of the planktonic foraminifer Globigerinoides sacculifer. Mar. Biol, 70, 73-86.

Bender, M.L., Lorens, R.B., Williams, D.F., 1975. Sodium, magnesium and strontium in the tests of planktonic foraminifera. Micropaleontology 21, 448-459.

Bentov, S., Erez, J., 2005. Novel observations on biomineralization processes in foraminifera and implications for $\mathrm{Mg} / \mathrm{Ca}$ ratio in the shells. Geology 33, 841-844. 
Bentov, S., Erez, J., 2006. Impact of biomineralization process on the $\mathrm{Mg}$ content of foraminiferal shells: A biological perspective. Geochem. Geophy. Geosy. 7, doi:10.1029/2005GC001015.

Bentov, S., Brownlee, C., Erez, J., 2009. The role of seawater endocytosis in the biomineralization process in calcareous foraminifera. P. Natl. Acad. Sci. USA 106, 21500-21504.

Berthold, W.U., 1976. Ultrastructure and function of wall perforations in Patellina corrugate Williamson, Foraminifera. J. Foramin. Res. 6, 22-29.

Bijma, J., Spero, H.J., Lea, D.W., 1999. Reassessing foraminiferal stable isotope geochemistry: Impact of the oceanic carbonate system (experimental results). Use of Proxies in Paleoceanography: Examples from the South Atlantic. G. Fischer and G. Wefer. Berlin, Heidelberg, Springer-Verlag: 489-512.

Boyle, E., 1981. Cadmium, zinc, copper, and barium in foraminiferal tests. Earth Planet. Sci. Lett. 53, 11-35.

Brummer, G.J., Hemleben, C., Spindler, M., 1987. Ontogeny of extant spinose planktonic foraminifera (Globigerinidae): a concept exemplified by Globigerinoides sacculifer (Brady) and G. ruber (D'Orbigny). Mar. Micropaleontol. 12, 357-381.

Brummer, G.J.A., Kroon, D., 1988. Planktonic foraminifers as tracers of ocean-climate history. Free University Press, Amsterdam, 346 pp.

Carafoli, E., Santella, L., Branca, D., Brini, M., 2001. Generation, control, and processing of cellular calcium signals. Crit. Rev. Biochem. Mol. 36, 107-260.

Caron, D.A., Bé, A.W.H., Anderson, O.R., 1982. Effects of variations in light intensity on life processes of the planktonic foraminifer Globigerinoides sacculifer in laboratory culture. J. Mar. Biol. Assoc. UK 62, 435-451. 
767 De Nooijer, L.J., Toyofuku, T., Kitazato, H., 2009a. Foraminifera promote calcification by 768 elevating their intracellular pH. P. Natl. Acad. Sci. USA 106, 15374-15378.

769 De Nooijer, L.J., Langer, G., Nehrke, G., Bijma, J., 2009b. Physiological controls on the seawater uptake and calcification in the benthic foraminifer Ammonia tepida. Biogeosciences 6, 2669-2675.

De Yoreo, J.J., Velikov, P.G., 2003. Principles of crystal nucleation and growth. Rev. Mineral. Geochem. 54, 57-94.

774

775

776

777

778

779

DePaolo, D.J., 2011. Surface kinetic model for isotopic and trace element fractionation during precipitation of calcite from aqueous solution. Geochim. Cosmochim. Ac. 75, 10391056.

Dissard, D., Nehrke, G., Reichart, G.J., Bijma, J., 2010. Impact of seawater $p \mathrm{CO}_{2}$ on calcification and $\mathrm{Mg} / \mathrm{Ca}$ and $\mathrm{Sr} / \mathrm{Ca}$ ratios in benthic foraminiferal calcite: results from culturing experiments with Ammonia tepida. Biogeosciences 7, 81-93.

Dove, P.M., De Yoreo, J.J., Weiner, S., 2003. Biomineralization: Reviews in Mineralogy and Geochemistry 54, Mineralogical Society of America. Washington DC, $381 \mathrm{pp.}$

Drake, S.K., Lee, K.L., Falke, J.J., 1996. Tuning the equilibrium ion affinity and selectivity of the EF-Hand calcium binding motif: Substitutions at the gateway position. Biochem 35, 6697-6705.

Duckworth, D.L., 1977. Magnesium concentration in the tests of the planktonic foraminifer Globorotalia truncatulinoides. J. Foramin. Res. 7, 304-312.

Dueñas-Bohórquez, A., Raitzsch, M., De Nooijer, L.J., Reichart, G.J., 2010. Independent impacts of calcium and carbonate ion concentration on $\mathrm{Mg}$ and $\mathrm{Sr}$ incorporation in cultured benthic foraminifera. Mar. Micropaleontol, 81, 122-130. 
Eggins, S.M., Sadekov, A., De Deckker, P., 2004. Modulation and daily banding of $\mathrm{Mg} / \mathrm{Ca}$ in Orbulina universa tests by symbiont photosynthesis and respiration: a complication for seawater thermometry? Earth Planet. Sci. Lett. 225, 411-419.

Elderfield, H., Bertram, C.J., Erez, J., 1996. A biomineralization model for the incorporation of trace elements into foraminiferal calcium carbonate. Earth Planet. Sci. Lett. 142, 409423.

Epstein, S., Buchsbaum, R., Lowenstam, H., Urey, H.C., 1951. Carbonate-water isotopic temperature scale. Bull. Geol. Soc. Am. 62, 417-426.

Erez, J., 1978. Vital effect on stable-isotope composition seen in foraminifera and coral skeletons. Nature 273, 199-202.

Erez, J., 1983. Calcification rates, photosynthesis and light in planktonic foraminifera. In: P. Westbroek, E.W. de Jong (eds), Biomineralization and biological metal accumulation. Reidel Publishing Company. 307-312.

Erez, J., 2003. The source of ions for biomineralization in foraminifera and their implications for paleoceanographic proxies. Rev. Mineral. Geochem. 54, 115-149.

Glas, M., Langer, G., Keul, N., 2012. Calcification acidifies the microenvironment of a benthic foraminifer (Ammonia sp.). J. Exp. Mar. Biol. Ecol. 424-425, 53-58.

Gouaux, E., MicKinnon, R., 2005. Principles of selective ion transport in channels and pumps. Science 310, 1461-1465.

Gonçalves, P.P., Meireles, S.M., Gravato, C., Vale, M.G.P., 1998. $\mathrm{Ca}^{2+}-\mathrm{H}^{+}$-antiport activity in synaptic vesicles isolated from sheep brain cortex. Neurosci. Lett. 247, 87-90.

Gonçalves, P.P., Meireles, S.M., Neves, P., Vales, M.G.P., 1999. Ion selectivity of the $\mathrm{Ca}^{2+} / \mathrm{H}^{+}$antiport in synaptic vesicles of sheep brain cortex. Mol. Brain Res. 67, 283-291.

Grossman, E.L., 1987. Stable isotopes in modern benthic foraminifera: A study of vital effect. J. Foramin. Res. 17, 48-61. 
815 Gussone, N., Eisenhauer, A., Heuser, A., Dietzel, M., Bock, B., Böhm, F., Spero, H.J., Lea, 816 D.W., Bijma, J., Nägler, T.F., 2003. Model for kinetic effects on calcium isotope 817 fractionation $\left(\delta^{44} \mathrm{Ca}\right)$ in inorganic aragonite and cultured planktonic foraminifera. 818 Geochim. Cosmochim. Ac. 67, 1375-1382.

819 Hamilton, C.P., Spero, H.J., Bijma, J., Lea, D.W., 2008. Geochemical investigation of 820 gametogenic calcite addition in the planktonic foraminifera Orbulina universa. Mar. $821 \quad$ Micropaleontol. 68, 256-267.

822 Hastings, D.W., Russell, A.D., Emerson, S.R., 1998. Foraminiferal magnesium in 823 Globigerinoides sacculifer as a paleotemperature proxy. Paleoceanography 13, 161-169.

824 Hathorne, E.C., James, R.H., Lampitt, R.S., 2009. Environmental versus biomineralization 825 controls on the intratest variation in the trace element composition of the planktonic

Hemleben, C., 1975. Spine and pustule relationships in some recent planktonic foraminifers. Micropaleontology 21, 334-341.

Hemleben, C., Bé, A.W.H., Anderson, O.R., Tuntivate, S., 1977. Test morphology, organic layers and chamber formation in the planktonic foraminifer Globorotalia menardii (d'Orbigny). J. Foramin. Res. 7, 1-25.

Hemleben, C., Spindler, M., Breitinger, I., Deuser, WG., 1985. Field and laboratory studies on the ontogeny and ecology of some Globorotaliid species from the Sargasso Sea off Bermuda. J. Foramin. Res. 15, 254-272.

Hemleben, C., Anderson, O.R., Berthold, W., Spindler, M., 1986. Calcification and chamber formation in Foraminifera - a brief overview. In: Leadbeater BS, Riding R (eds), The systematics association, special volume $30,237-249$. 
839 Hemleben, C., M. Spindler, Anderson, O.R., 1989. Modern planktonic foraminifera. New $840 \quad$ York, Springer, 363 pp.

841 Hemleben, C., Mühlen, D., Olsson, R.K., Berggren, W.A., 1991. Surface texture and first 842 occurrence of spines in planktonic foraminifera from the early Tertiary. Geologisches $843 \quad$ Jahrbuch A 128, 117-146.

844 Hemleben, C., Bijma, J., 1994. Foraminiferal population dynamics and stable carbon isotopes. $845 \quad$ NATO ASI series $117,145-166$.

846 Higgins, C.F., 1992. ABC transporters: from microorganisms to man. Annu. Rev. Cell Biol. 8, 67-113.

Hönisch, B., Allen, K.A., Lea, D.W., Spero, H.J., Eggins, S.M., Arbuszewski, J., deMenocal, 849 P., Rosenthal, Y., Russell, A.D., Elderfield, H., 2013. The influence of salinity on $\mathrm{Mg} / \mathrm{Ca}$ in planktic foraminifers - Evidence from cultures, core-top sediments and complementary $\delta^{18}$ O. Geochim. Cosmochim. Acta 121, 196-213.

Hottinger, L., Dreher, D., 1974. Differentiation of protoplasm in Nummulitidae (Foraminifera) from Elat, Red Sea. Mar. Biol. 25, 41-61.

Ishikawa, M., Ichikuni, M., 1984. Uptake of sodium and potassium by calcite. Chem. Geol. $42,137-146$

Jørgensen, B.B., Erez, J., Revsbech, N.P., Cohen, Y., 1985. Symbiotic photosynthesis in a planktonic foraminiferan Globigerinoides sacculifer (Brady), studied with microelectrodes. Limnol. Oceonogr. 30, 1253-1267.

Katz, A., 1973. The interaction of magnesium with calcite during crystal growth at $25-90^{\circ} \mathrm{C}$ and one atmosphere. Geochim. Cosmochim. Ac. 37, 1563-1586.

Katz, M.E., Cramer, B.S., Franzese, A., Hönisch, B., Miller, K.G., Rosenthal, Y., Wright, J.D., 2010. Traditional and Emerging geochemical proxies in foraminifera. J. Foramin. Res. 40, 165-192. 
King, K., Hare, P.E., 1972. Amino acid composition of the test as a taxonomic character of living and fossil planktonic foraminifera. Micropaleonontology 18, 285-293.

Kitano, Y., Okumura, M., Idogaki, M., 1975. Incorporation of sodium, chloride and sulfate with calcium carbonate. Geochem. J. 9, 75-84.

Kitazato, H., Bernhard J.M., 2014.Approaches to study living foraminifera: collection, maintainance and experimentation. Springer, $227 \mathrm{pp}$.

Köhler-Rink, S., Kühl, M., 2000. Microsensor studies of photosynthesis and respiration in larger symbiotic foraminifera. I The physico-chemical microenvironment of Marginopora vertebralis, Amphistegina lobifera and Amphisorus hemprichii. Mar. Biol. $137,473-486$.

Köhler-Rink, S., Kühl, M., 2005. The chemical microenvironment of the symbiotic planktonic foraminifer Orbulina universa. Mar. Biol. Res. 1, 68-78.

Kozdon, R., Ushikubo, T., Kita, N.T., Spicuzza, M., Valley, J.W., 2009. Intratest oxygen isotope variability in the planktonic foraminifer $N$. pachyderma: real vs. apparent vital effects by ion microprobe. Chem. Geol. 258, 327-337.

Kunioka, D., Shirai, K., Takahata, N., Sano, Y., Toyofuku, T., Ujiie, Y., 2006. Microdistribution of $\mathrm{Mg} / \mathrm{Ca}, \mathrm{Sr} / \mathrm{Ca}$, and $\mathrm{Ba} / \mathrm{Ca}$ ratios in Pulleniatina obliquiloculata test by using a NanoSIMS: Implication for the vital effect mechanism. Geochem. Geophy. Geosy. 7, doi: 10.1029/2006GC001280.

Langer, M.R., 1992. Biosynthesis of glycosaminoglycans in foraminifera: A review. Marine Micropaleontology 19, 245-255.

Lea, D.W., Boyle, E.A., 1991. Barium in planktonic foraminifera. Geochim. Cosmochim. Ac. $55,3321-3331$. 
887 Lea, D.W., Spero, H.J., 1992. Experimental determination of barium uptake in shells of the planktonic foraminifera Orbulina universa at $22^{\circ} \mathrm{C}$. Geochim. Cosmochim. Ac. 56, 2673-2680.

890

891

892

Lea, D.W., Martin, P.A., Chan, D.A., Spero, H.J., 1995. Calcium uptake and calcification ratae in planktonic foraminifer Orbulina universa. J. Foramin. Res. 25, 14-23.

Lea, D.W., Mashoitta, T.A., Spero, H.J., 1999. Controls on magnesium and strontium uptake in planktonic foraminifera determined by live culturing. Geochim. Cosmochim. Ac. 63, 2369-2379.

Lea, D.W., Pak, D.K., Spero, H.J., 2000. Climate impact of late Quaternary equatorial Pacific sea surface temperature variations. Science 289, 1719-1724.

Lear, C.H., Elderfield, H., Wilson, P.A., 2000. Cenozoic deep-sea temperatures and global ice volumes from $\mathrm{Mg} / \mathrm{Ca}$ ratios in benthic foraminiferal calcite. Science 287, 269-272.

Lee, J.J., Anderson, O.R. (eds), 1991. Biology of Foraminifera, Academic Press, London, 368 pp.

Lehninger, A.L., Rossi, C.S., Greenawalt, J.W., 1963. Respiration-dependent accumulation of inorganic phosphate and $\mathrm{Ca}^{2+}$ by rat liver mitochondria. Biochem. Biophy. Res. Comm. $10,444-448$.

Lowenstam, H.A., Weiner, S., 1989. Biomineralization. Oxford University Press. pp xxx.

Mann, S., 1988. Molecular recognition in biomineralization. Nature 332, 119-124.

Marriott, C.S., Henderson, G.M., Belshaw, N.S., Tudhope, A.W., 2004. Temperature dependence of $\delta^{7} \mathrm{Li}, \delta^{44} \mathrm{Ca}$ and $\mathrm{Li} / \mathrm{Ca}$ during growth of calcium carbonate. Earth Planet. Sci. Lett. 222, 615-624.

Marsh, M.E., 2003. Regulation of $\mathrm{CaCO}_{3}$ formation in coccolithophores. Comp. Biochem. Physiol. B. Biochem. Mol. Biol. 236,743-754. 
911 McConnaughey, T.A., Whelan, J.F., 1997. Calcification generates protons for nutrient and 912 bicarbonate uptake. Earth-Sci. Rev. 42, 95-117.

913 McCrea, J.M., 1950. On the isotopic chemistry of carbonates and a paleotemperature scale. J. $914 \quad$ Chem. Phys. 18, 849-857.

915 Morse, J.W., Arvidson, R.S., Lüttge, A., 2007. Calcium carbonate formation and dissolution. $916 \quad$ Chem. Rev. 107, 342-381.

917 Morse, J.W., Bender, M.L., 1990. Partition coefficients in calcite: Examination of factors 918 influencing the validity of experimental results and their application to natural systems. $919 \quad$ Chem. Geol. 82, 265-277.

920 Mucci, A., 1987. Influence of temperature on the composition of magnesian calcite 921 overgrowths precipitated from seawater. Geochim. Cosmochim. Ac. 51, 1977-1984.

922 Nehrke, G., Nouet, J., 2011. Confocal Raman microscope mapping as a tool to describe 923 different mineral phases at high spatial resolution within marine biogenic carbonates: a 924 case study on Nerita undata (Gastropoda, Neritopsina). Biogeosciences 8, 3761-3769.

925 Nehrke, G., Poigner, H., Wilhelms-Dick, D., Brey, T., Abele, D., 2012. Coexistence of three 926 calcium carbonate polymorphs in the shell of the Antarctic clam Laternula elliptica. 927 Geochem. Geophys. Geosys. 13, Q05014.

928 Nehrke, G., Keul, N., Langer, G., De Nooijer,. L.J., Bijma, J., 2013. A new model for 929 biomineralization and trace-element signatures of Foraminifera tests. Biogeosciences 10, $930 \quad 6759-6767$.

931 Nudelman, F., Gotliv, B.A., Addadi, L., Weiner, S., 2006. Molusk shell formation: mapping 932 the distribution of organic matrix components underlying a single aragonitic tablet in 933 nacre. J. Struc. Biol. 153, 176-178. 
934 Nürnberg, D., Bijma, J., Hemleben, C., 1996. Assessing the reliability of magnesium in 935 foraminiferal calcite as a proxy for water mass temperature. Geochim. Cosmochim. Ac. $936 \quad 60,803-814$.

937 Ogawa, T., Kaplan, A., 1987. The stoichiometry between $\mathrm{CO}_{2}$ and $\mathrm{H}^{+}$fluxes involved in the 938 transport of inorganic carbon in cyanobacteria. Plant Physiol. 83, 888-891.

939 Olsson, R.K., 1976. Wall structure, topography and crust of Globigerina pachyderma 940 (Ehrenberg). Progress in Micropaleontology: 1-9.

941 Pereira, A.C., Samellas, D., Tiffert, T., Lew, V.L., 1993. Inhibition of the calcium pump by high cytosolic $\mathrm{Ca}^{2+}$ in intact human red blood cells. J. Physiol. 461, 63-73.

943 Pingitore, N.E., Eastman, M.P., 1984. The experimental partitioning of $\mathrm{Ba}^{2+}$ into calcite. $944 \quad$ Chem. Geol. 45, 113-120.

945 Raz, S., Weiner, S., Addadi, L., 2000. Formation of high-magnesian calcites via an 946 amorphous precursor phase: possible biological implications. Adv. Mater. 12, 38-42.

947 Reiss, Z., 1957. The Bilamellidea, nov. superfam., and remarks on Creteceous globorotaliids. 948 Cushman Foundation Foramin. Res. Contr. 8, 127-145.

949 Reiss, Z., 1960. Structure of so-called Eponides and some other Rotaliiform Foraminifera. 950 Ministry of Development Geological Survey 29, 1-29.

951 Rickaby, R.E.M., Elderfield, H., 1999. Planktonic foraminiferal Cd/Ca: paleonutrients or 952 paleotemperature? Paleoceanography 14, 293-303.

953 Rimstidt, D.J., Balog, A., Webb, J., 1998. Distribution of trace elements between carbonate 954 minerals and aqueous solutions. Geochim. Cosmochim. Ac. 62, 1851-1863.

955 Rink, S., Kühl, M., Bijma, J., Spero, H.J., 1998. Microsensor studies of photosynthesis and 956 respiration in the symbiotic foraminifer Orbulina universa. Mar. Biol. 131, 583-595.

957 Robbins, L.L., Brew, K., 1990. Proteins from the organic matrix of core-top and fossil 958 planktonic foraminifera. Geochim. Cosmochim. Ac. 54, 2285-2292. 
Robbins, L.L., Healy-Williams, N.H., 1991. Toward a classification of planktonic foraminifera based on biochemical, geochemical, and morphological criteria. J. Foramin. Res. 21, 159-167.

Saito, T., Thompson, P.R., Breger, D., 1976. Skeletal ultra-microstructure of some elongatechambered planktonic Foraminifera and related species. In: Takayanagi Y, Saito T (eds), Selected papers in honor of Prof. Kiyoshi Asano. Progress in Micropaleontology Special Publication, 278-304.

Schmiedl, G., Mackensen, A., 2006. Multispecies stable isotopes of benthic foraminifers reveal past changes of organic matter decomposition and deep water oxygenation in the Arabian Sea. Paleoceanography 21, PA4213.

Segev, E., Erez, J., 2006. Effect of $\mathrm{Mg} / \mathrm{Ca}$ ratio in seawater on shell composition in shallow benthic foraminifera. Geochem. Geophy. Geosy. 7: Q02P09.

Shi, Y., Yu, C., Gu, Z., Zhan, X., Wang, Y., Wang, A., 2013. Characterization of the pearl oyster (Pinctada martensii) mantle transcriptome unravels biomineralization genes. Mar. Biotechnol. 15, 175-187.

Sinclair, D., Risk, M., 2006. A numerical model of trace element coprecipitation in a physicochemical calcification system: Application to coral biomineralization and trace element vital effects. Geochim. Cosmochim. Ac. 70, 3855-3868.

Spero, H.J., 1988. Ultrastructural examination of chamber morphogenesis and biomineralization in the planktonic foraminifer Orbulina universa. Mar. Biol. 99, 9-20.

Spero, H.J., Bijma, J., Lea, D.W., Bemis, B.E., 1997. Effect of seawater carbonate concentration on foraminiferal carbon and oxygen isotopes. Nature 390, 497-500.

Spindler, M., 1978. The development of the organic lining in Heterostegina depressa (Nummulitidae: Foraminifera). J. Foramin. Res. 8, 258-261. 
Tang, J., Niedermayr, A., Köhler, S.J., Böhm, F., Kisakürek, B., Eisenhauer, A., Dietzel, M., 2012. $\mathrm{Sr}^{2+} / \mathrm{Ca}^{2+}$ and ${ }^{44} \mathrm{Ca} /{ }^{40} \mathrm{Ca}$ fractionation during inorganic calcite formation: III. Impact of salinity/ ionic strength. Geochim. Cosmochim. Ac. 77, 432-443.

Taylor, A.R., Chrachri, A., Wheeler, G., Goddard, H., Brownlee, C., 2011. A voltage-gated $\mathrm{H}+$ channel underlying $\mathrm{pH}$ homeostasis in calcifying coccolithophores. PLoS Biol. 9: e1001085.

Ter Kuile, B., Erez, J., 1984. In situ growth rate experiments on the symbiont-bearing foraminifera Amphistegina lobifera and Amphisorus hemprichii. J. Foramin. Res. 14, 262-276.

Ter Kuile, B., Erez, J., 1987. Uptake of inorganic carbon and internal carbon cycling in symbiont-bearing benthonic foraminifera. Mar. Biol. 94, 499-509.

Ter Kuile, B., Erez, J., 1988. The size and function of the internal inorganic carbon pool of the foraminifer Amphistegina lobifera. Mar. Biol. 99, 481-487.

Ter Kuile, B., Erez, J., Padan, E., 1989a. Competition for inorganic carbon between photosynthesis and calcification in the symbiont-bearing foraminifer Amphistegina lobifera. Mar. Biol. 103, 253-259.

Ter Kuile, B., Erez, J., Padan, E., 1989b. Mechanisms for the uptake of inorganic carbon by two species of symbiont-bearing foraminifera. Mar. Biol. 103, 241-251.

Ter Kuile, B., Erez, J., 1991. Carbon budgets for two species of benthonic symbiont-bearing foraminifera. Biol. Bull. 180, 489-495.

Terakado, Y., Ofuka, Y., Tada, N., 2010. Rare earth elements, Sr, Ba, Fe, and major cation concentrations in some living foraminiferal tests collected from Iriomote Island, Japan: An exploration for trace element behavior during biogenic calcium carbonate formation. Geochem. J. 44, 315-322. 
Towe, K.M., Cifelli, R., 1967. Wall ultrastructure in the calcareous Foraminifera: crystallographic aspects and a model for calcification. J. Paleontol. 41, 742-762.

Toyofuku, T., De Nooijer, L.J., Yamamoto, H., Kitazato, H., 2008. Real-time visualization of calcium ion activity in shallow benthic foraminiferal cells using the fluorescent indicator Fluo-3 AM. Geochem. Geophy. Geosy. 9, Q05005, doi: 10.1029/2007GC001772.

Urey, H.C., Lowenstam, H.A., Epstein, S., McKinney, C.R., 1951. Measurement of paleotemperatures and temperatures of the upper Cretaceous of England, Denmark, and the Southeastern United States. Bull. Geol. Soc. Am. 62, 399-416.

Venn, A.A., Tambutté, E., Holcomb, M., Laurent, J., Allemand, D., Tambuté, S., 2013. Impact of seawater acidification on $\mathrm{pH}$ at the site of tissue-skeleton interface and calcification in reef corals. P. Natl. Acad. Sci. USA 110, 1634-1639.

Vetter, L., Kozdon, R., Mora, C.I., Eggins, S.M., Valley, J.W., Hönisch, B., Spero, H.J., 2013. Micron-scale intrashell oxygen isotope variation in cultured planktic foraminifers. Geochim. Cosmochim. Ac. 107, 1-12.

Wang, K.K.W., Villalobo, A., Roufogalis, B.D., 1992. The plasma membrane calcium pump: a multiregulated tranporter. Trends Cell Biol. 2, 46-52.

Weiner, S., Dove, P.M., 2003. An overview of biomineralization processes and the problem of the vital effect. Rev. Mineral. Geochem. 54, 1-29.

Weiner, S., Erez, J., 1984. Organic matrix of the shell of the foraminifer, Heterostegina depressa. J. Foramin. Res. 14, 206-212.

Wetmore, K., 1999. Chamber formation in Archaias ungulatus. J. Foramin. Res. 29, 69-74.

Wilson, J.E., Chin, A., 1991. Chelation of divalent cations by ATP, studied by titration calorimetry. Anal. Biochem. 193, 16-19.

Wolf-Gladrow, D., Bijma, J., Zeebe, R.E., 1999. Model simulation of the carbonate system in the microenvironment of symbiont bearing foraminifera. Mar. Chem. 64, 181-198. 
Zeebe, R.E., 1999. An explanation of the effect of seawater carbonate concentration on foraminiferal oxygen isotopes. Geochim. Cosmochim. Ac. 63, 2001-2007.

Zeebe, R.E., Bijma, J., Wolf-Gladrow, D.A., 1999. A diffusion-reaction model of carbon isotope fractionation in foraminifera. Mar. Chem. 64, 199-227.

Zeebe, R.E., Sanyal, A., 2002. Comparison of two potential strategies of planktonic foraminifera for house building: $\mathrm{Mg}^{2+}$ or $\mathrm{H}^{+}$removal? Geochim. Cosmochim. Ac. 66, 159-169.

Zeebe, R.E., Bijma, J., Hönisch, B., Sanyal, A., Spero, H.J., Wolf-Gladrow, D.A., 2008. Vital effects and beyond: a modeling perspective on developing palaeoceanographical proxy relationships in foraminifera. Geol. Soc., London Special Publications 303, 45-58.

Ziveri, P., Thoms, S., Probert, I., Geisen, M., Langer, G., 2012. A universal carbonate ion effect on stable oxygen isotope ratios in unicellular planktonic calcifying organisms. Biogeosciences 9, 1025-1032. 


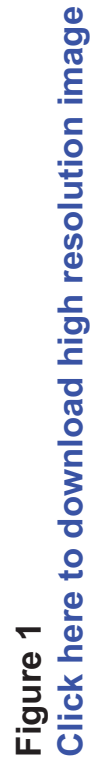

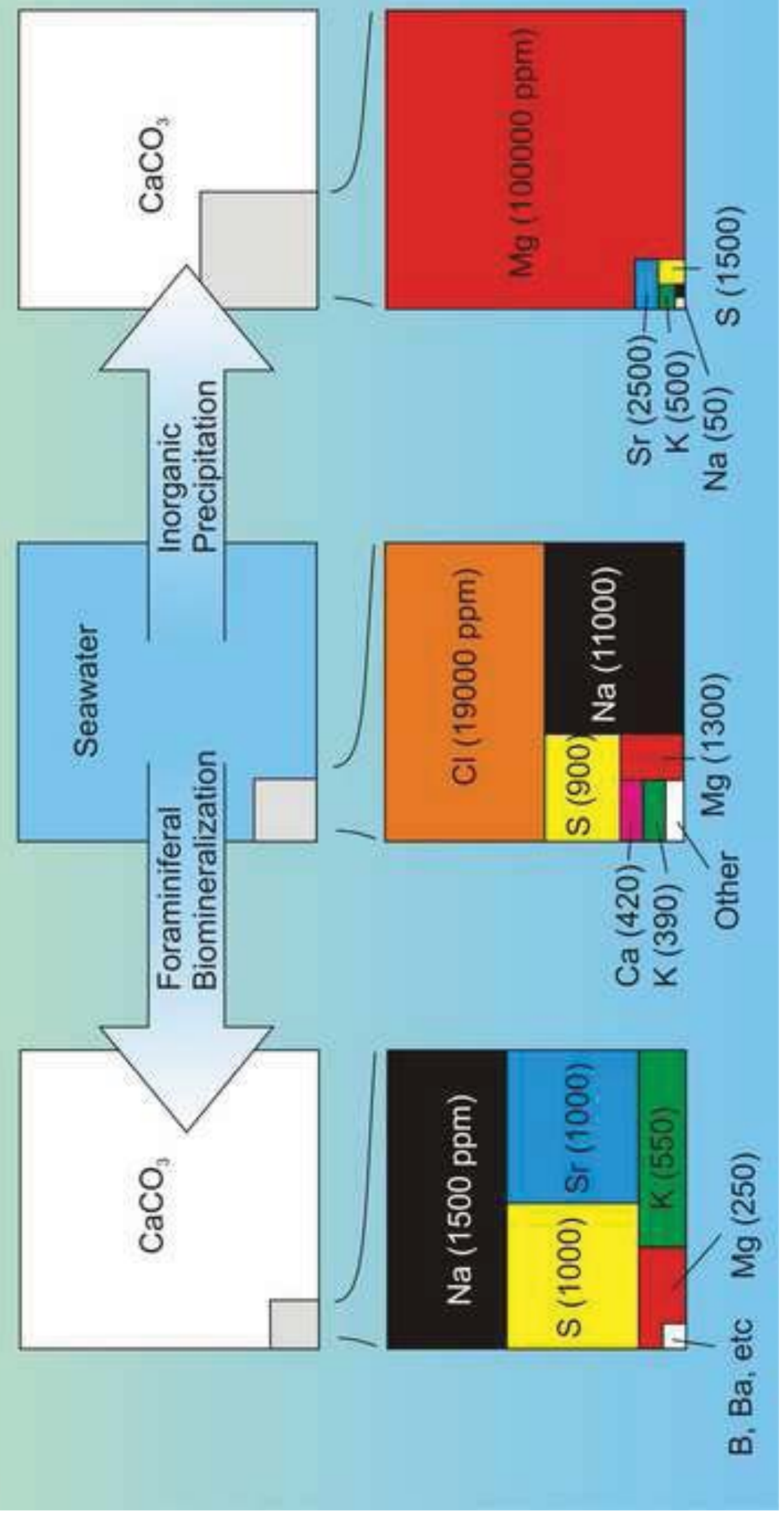




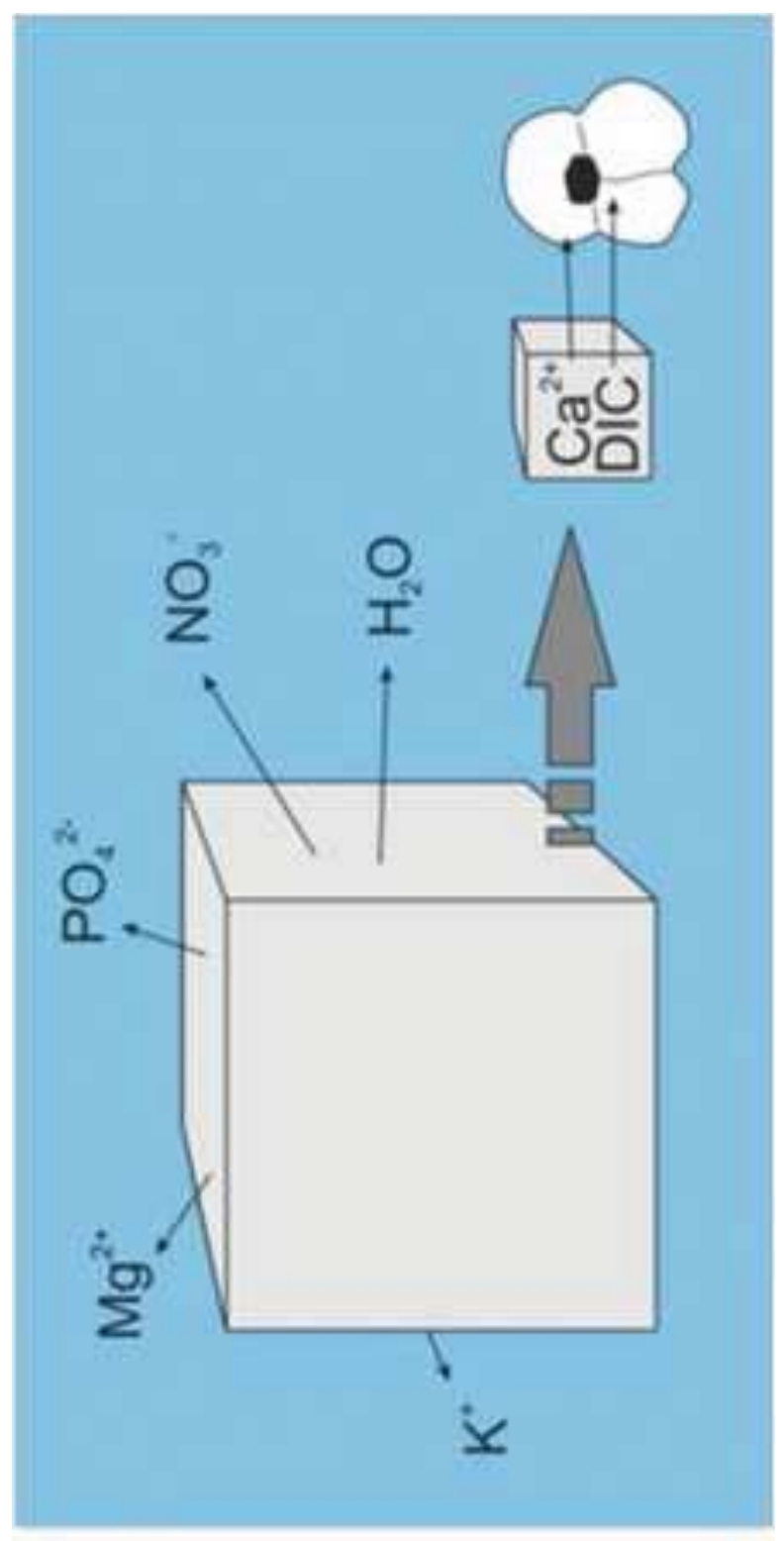

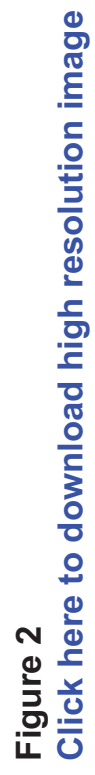

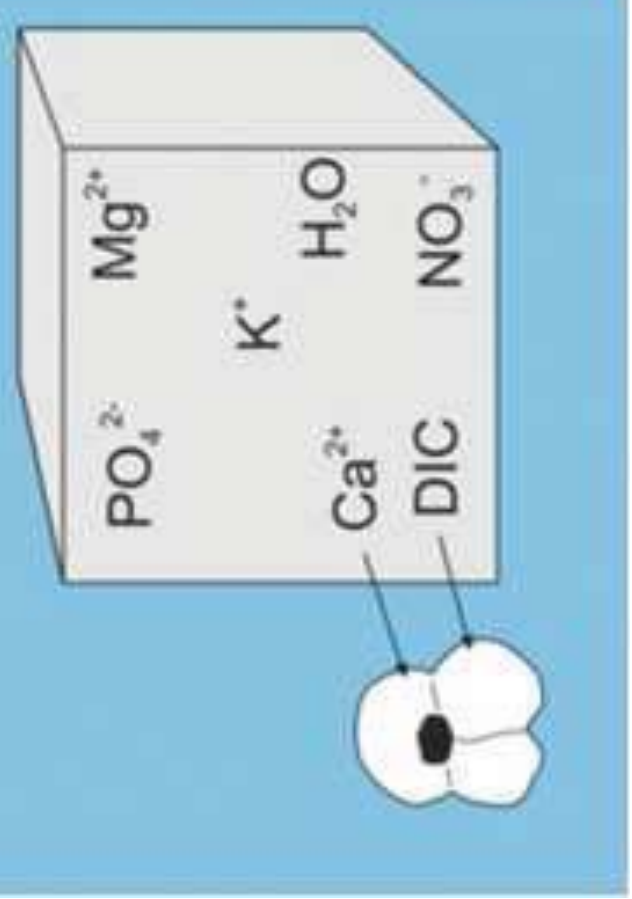



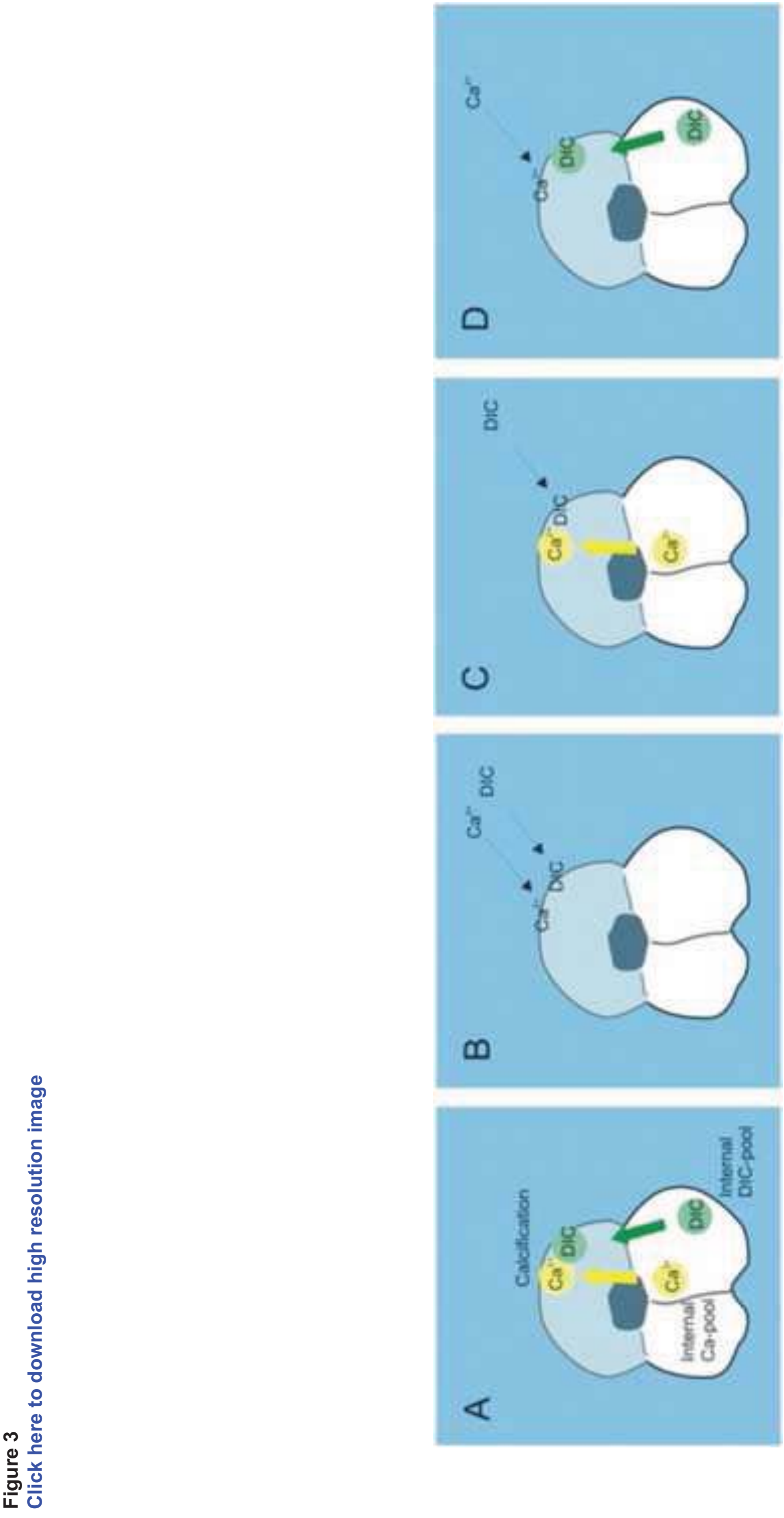


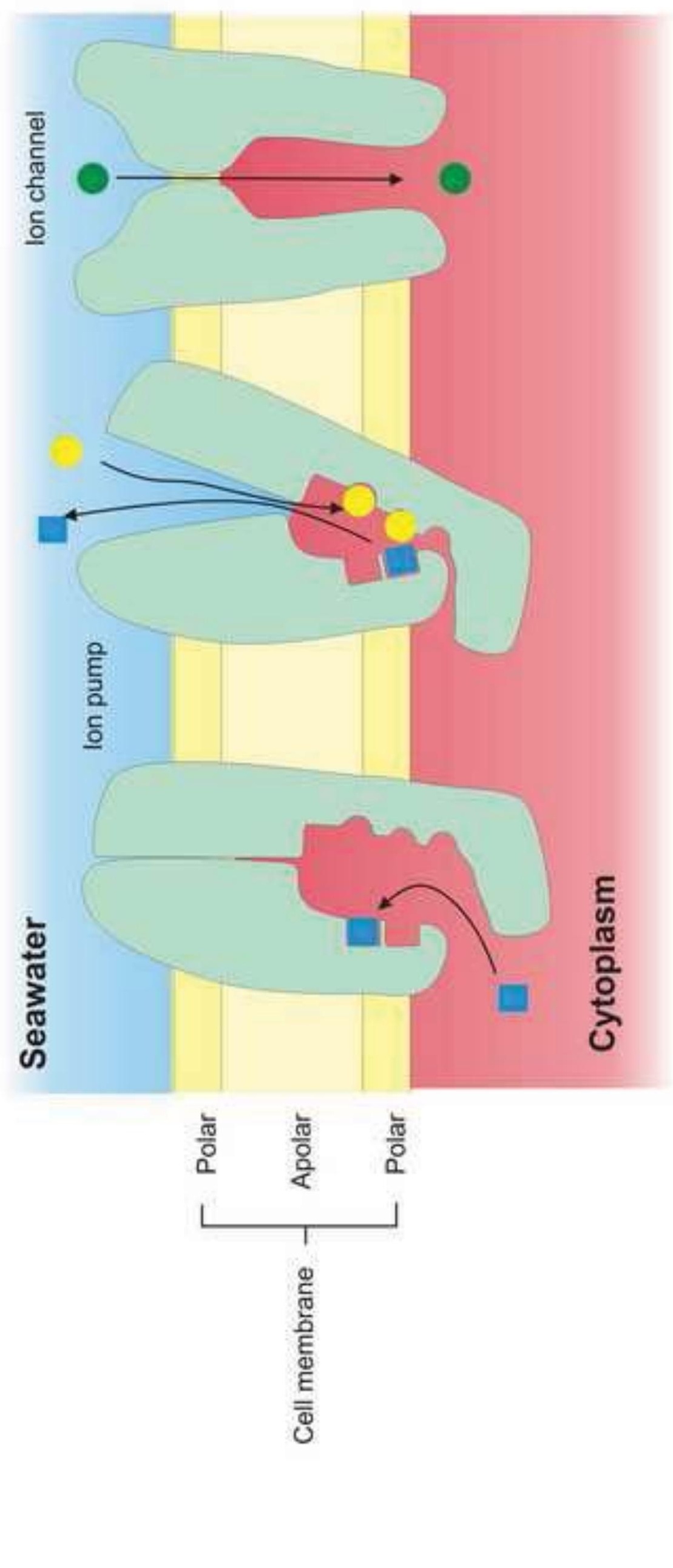




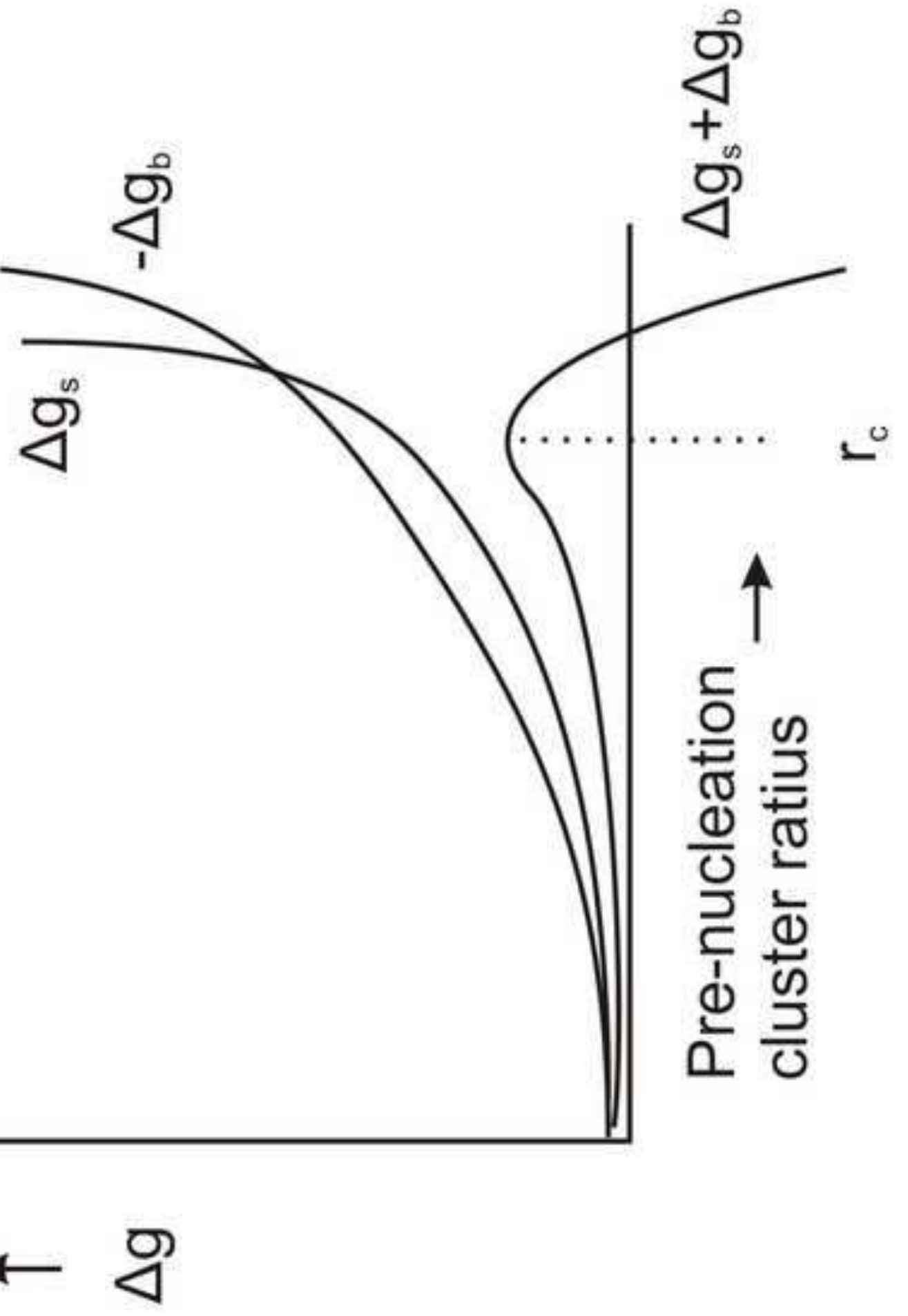




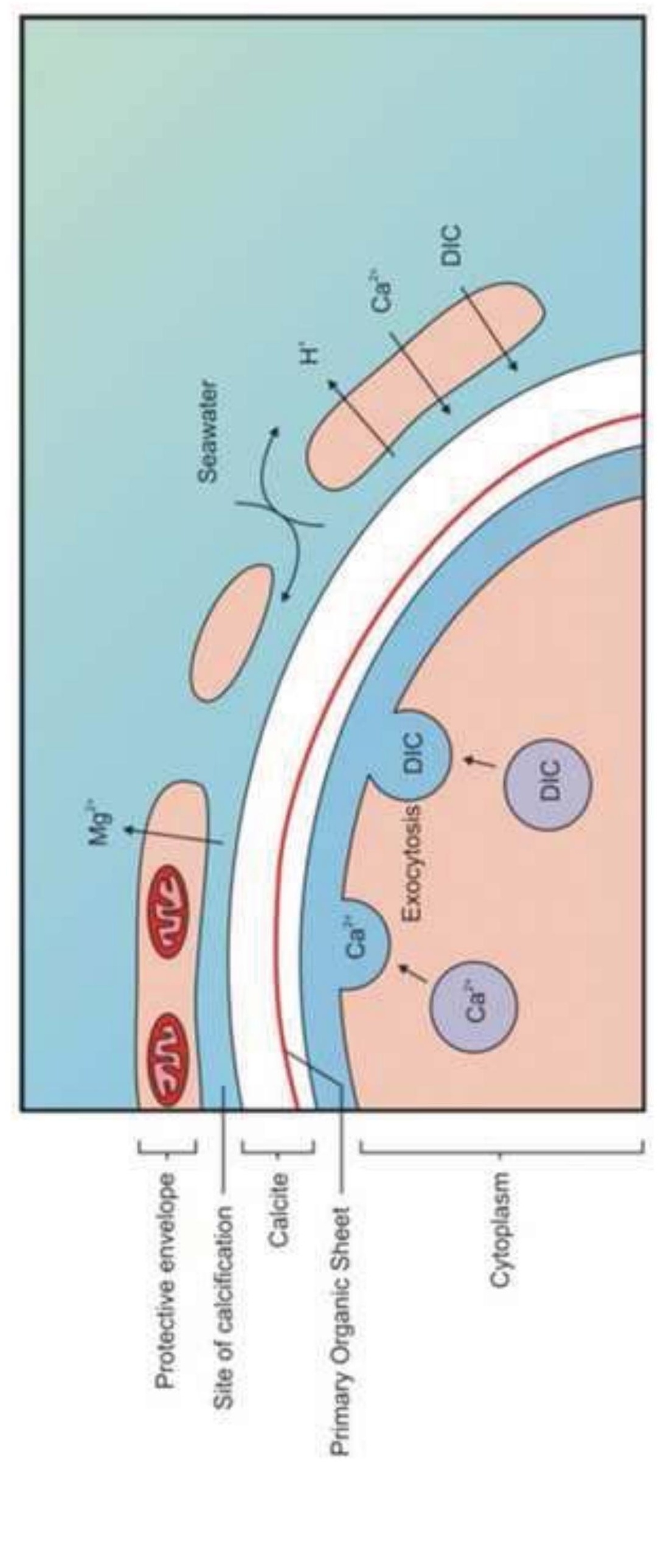


Table 1: Studies discussing internal reservoirs in perforate foraminifera.

\begin{tabular}{|c|c|c|}
\hline & $\mathrm{Ca}^{2+}$ reservoir & DIC reservoir \\
\hline $\begin{array}{ll}\text { Large } & \text { volume } \\
\text { reservoirs } & \end{array}$ & $\begin{array}{l}\text { Anderson and Faber (1984) } \\
\text { Erez (2003) } \\
\text { Toyofuku et al. (2008) }\end{array}$ & $\begin{array}{l}\text { Ter Kuile and Erez }(1987 ; 1988 ; \\
\text { 1989b; 1991) } \\
\text { Erez (1978; 1982) } \\
\text { Bentov et al. (2009) }\end{array}$ \\
\hline $\begin{array}{l}\text { No or small volume } \\
\text { reservoirs }\end{array}$ & $\begin{array}{l}\text { Angell (1979) } \\
\text { Lea et al. (1995) } \\
\text { Nehrke et al. (accepted) }\end{array}$ & Angell (1979) \\
\hline
\end{tabular}

